\title{
Diversity of marine benthic algae from Cantabria (Eastern Cantabrian, Spain): a historical overview of research and publications
}

\author{
${\text { Eduardo } \text { Cires }^{1,2} \text { (D) } \cdot \text { Candela Cuesta }}^{1,3}$ (D)
}

Received: 23 June 2021 / Accepted: 13 December 2021 / Published online: 10 January 2022

(c) The Author(s) 2022

\begin{abstract}
The macroalgal flora of Cantabria (north of Spain) has attracted the interest of many researchers on past occasions. Currently published information only reflects occasional collections from sporadic field visits to this region of the Spanish Atlantic coast. To overcome this, a historical overview of research and publications, encompassing collections and presence data recording, has been undertaken. This work lists the resultant taxonomic records and provides information about macroalgal flora of Cantabria. A total of 425 species (25 Cyanobacteria, 55 Chlorophyta, 81 Ochrophyta, and 264 Rhodophyta) were identified. The number of specific, infraspecific taxa, and stages is 437: 25 Cyanobacteria, 57 Chlorophyta, 89 Ochrophyta, and 266 Rhodophyta. The floristic character of flora from the Cantabrian coast is compared over time and with nearby regions applying Cheney's ratio [(Rhodophyta+Chlorophyta)/ Ochrophyta, or $(\mathrm{R}+\mathrm{C}) / \mathrm{O}$ ]. The present paper aims to provide an overview of the research that has been conducted in the Cantabrian coast, not only found in international publications but also in local publications as well as unpublished theses.
\end{abstract}

Keywords Cantabria $\cdot$ Chlorophyta $\cdot$ Cyanobacteria $\cdot$ Flora $\cdot$ Iberian Peninsula $\cdot$ NE Atlantic $\cdot$ Ochrophyta $\cdot$ Rhodophyta Seaweeds $\cdot$ Spain

\section{Introduction}

Marine benthic flora of the Atlantic coasts of the Iberian Peninsula has been studied for over 250 years (e.g., Clemente y Rubio 1807; Colmeiro 1867, 1889; Lázaro e Ibiza 1889); Sauvageau 1897; Chalon 1905; Miranda 1931; Dizerbo 1956, etc.) and, currently, many species are catalogued in various checklists or compilations (e.g. Miranda 1943a, b, c, 1944; Ardré 1970; Cremades et al. 2002; Gorostiaga et al. 2004; Araújo et al. 2003, 2009; Bárbara et al. 2003, 2005; Cires and Cuesta 2010, 2019). In recent years, new floristic contributions have increased our knowledge

Eduardo Cires

cireseduardo@uniovi.es

1 Departamento de Biología de Organismos y Sistemas, Universidad de Oviedo, C/ Catedrático Rodrigo Uría s/n, 33071 Oviedo, Spain

2 Instituto de Recursos Naturales y Ordenación del Territorio (INDUROT), Campus de Mieres, C/ Gonzalo Gutiérrez Quirós s/n, 33600 Mieres, Spain

3 Escuela Politécnica de Mieres (EPM), $3^{\text {a }}$ Planta Ala Sur. C/ Gonzalo Gutiérrez Quirós s/n, 33600 Mieres, Spain of the algae in the north of the Iberian Peninsula, and new research at the molecular level has been developed, enriching the traditional systematics.

However, within the Iberian coast, Cantabrian marine benthic flora is scarcely known to the point that no detailed checklist of the region has been developed. Some lists focused on the Western and Eastern stretches of the coast were published (Fernández-Montero et al. 1998; Menoyo et al. 1998) and later expanded (Martínez-Gil et al. 2007), which verse around the benthic marine algae from Noja (Cantabria). Although these works add up a total of 252 species to the marine flora of the province, a much higher value is found in neighboring territories (Fig. 1).

Thus, the present work aims to expand the knowledge on the marine algae flora of the coast of Cantabria for the first time. It is worth highlighting that a thorough knowledge of natural resources of a territory is always required, not only for a proper evaluation and conservation management, but also as it constitutes an exceptionally valuable source of scientific information. Therefore, this inventory does not attempt to be a definitive catalogue, as new records appear continuously, but to contribute to increase our understanding of the biogeographical characteristics of this area in the 


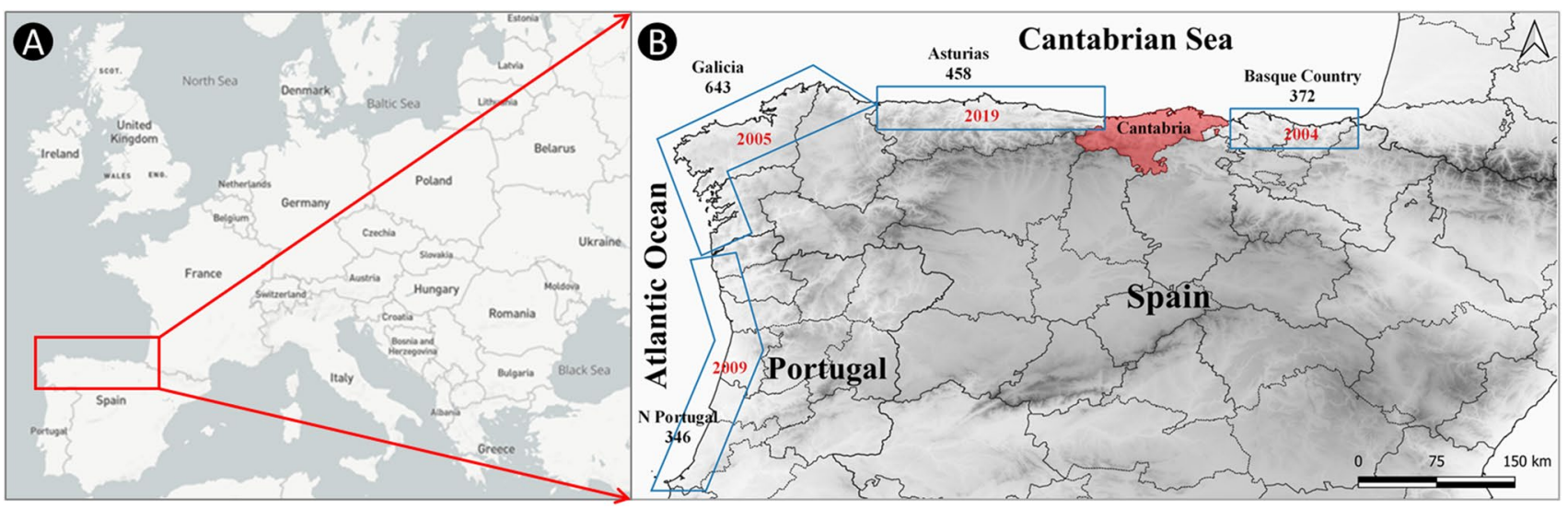

Fig. 1 Map showing the location of Cantabria and the regions with which its flora is compared. (A) Study area of the present work. (B) Map showing the location of Atlantic provinces. Red: publication year of the checklist or compilation - North of Portugal (Araújo et al.

Atlantic coast and the knowledge of its marine biodiversity, which altogether may be useful for the sustainable management of the future marine protected area.

\section{Materials and methods}

\section{Description of study area and applied methodology}

The coast of the Cantabria region, between $43^{\circ} 21^{\prime} \mathrm{N}, 3^{\circ} 09^{\prime}$ $\mathrm{W}$ and $43^{\circ} 23^{\prime} \mathrm{N}, 4^{\circ} 30^{\prime} \mathrm{W}$ covers about $220 \mathrm{~km}$ (Fig. 1). It borders Asturias to the west at Tina Mayor, a small estuary formed by the mouth of Deva river, while to the east it borders the Basque Country. It is characterized by extensive cliffs (approximately $136 \mathrm{~km}$ are occupied by cliffs). In short, it is a steep coast with many geographical features (e.g., wave-cut platformer beach, estuaries, bays, headlands and beaches). The climate is temperate, oceanic, with moderate winters and warm summers.

This catalogue compiles an intensive search of scientific information related to benthic marine algae from the Cantabrian coast. The checklist is based on a compilation of data from literature references and herbarium data. For the literature survey, international publications on macroalgae where Cantabria is cited were retrieved from four different search engines, i.e., the Web of Science (https://clari vate.com/webofsciencegroup/), ScienceDirect (https://www. sciencedirect.com/), Scopus (https://www.scopus.com) and Google Scholar (https://scholar.google.com/). Subsequently, inquiries were made regarding papers that were published locally in journals of different local universities and in final reports of national and international projects. The last step was to obtain unpublished works such as M. Phil. Thesis, Ph.D. Doctoral Thesis and Technical Reports from
2009), Galicia (Bárbara et al. 2005), Asturias (Cires and Cuesta 2010, 2019); Basque Country (Gorostiaga et al. 2004). Black: number of algae listed

universities and scientific institutions. The herbarium specimens checked belong to University of Oviedo (FCO-Algae), Royal Botanic Garden of Madrid (MA-Algae), University of Barcelona (BCN-Phycophyta), Complutense University of Madrid (MACB-Algae), University of Valencia (VALAlgae), University of País Vasco (BIO-Algae), University of Santiago de Compostela (SANT-Algae) and The French National Museum of Natural History (Muséum National d'Histoire Naturelle, PC-cryptogamy) (see GBIF 2021; https://www.gbif.org/).

The current taxonomic status and nomenclatural changes of the taxa of interest have been considered following Algaebase (https://www.algaebase.org/; Guiry and Guiry 2021). Phyla, class, orders, families, genera and species are alphabetically arranged. To classify the Cantabrian algae flora, we have applied Feldmann's ratio [R/O] (number of species of Rhodophyta / number of species of Ochrophyta) and Cheney's ratio $[(\mathrm{R}+\mathrm{C}) / \mathrm{O}]$ in a similar manner to Feldmann's but including green algae (Feldmann 1937 and Cheney 1977 respectively). These ratios indicate the position of a flora in relation to cold and warm waters.

\section{Results}

Table 1 presents the checklist of the seaweeds of Cantabria in taxonomic order. It includes most synonyms used in literature, bibliographic references and herbarium sheets. The list includes 425 species: 25 Cyanobacteria, 55 Chlorophyta, 81 Ochrophyta, and 264 Rhodophyta. The number of specific, infraspecific taxa, and stages is 437: 25 Cyanobacteria, 57 Chlorophyta, 89 Ochrophyta, and 266 Rhodophyta. We have also excluded 7 species from the coast of Cantabria due to misidentifications, and considered doubtful the presence of 


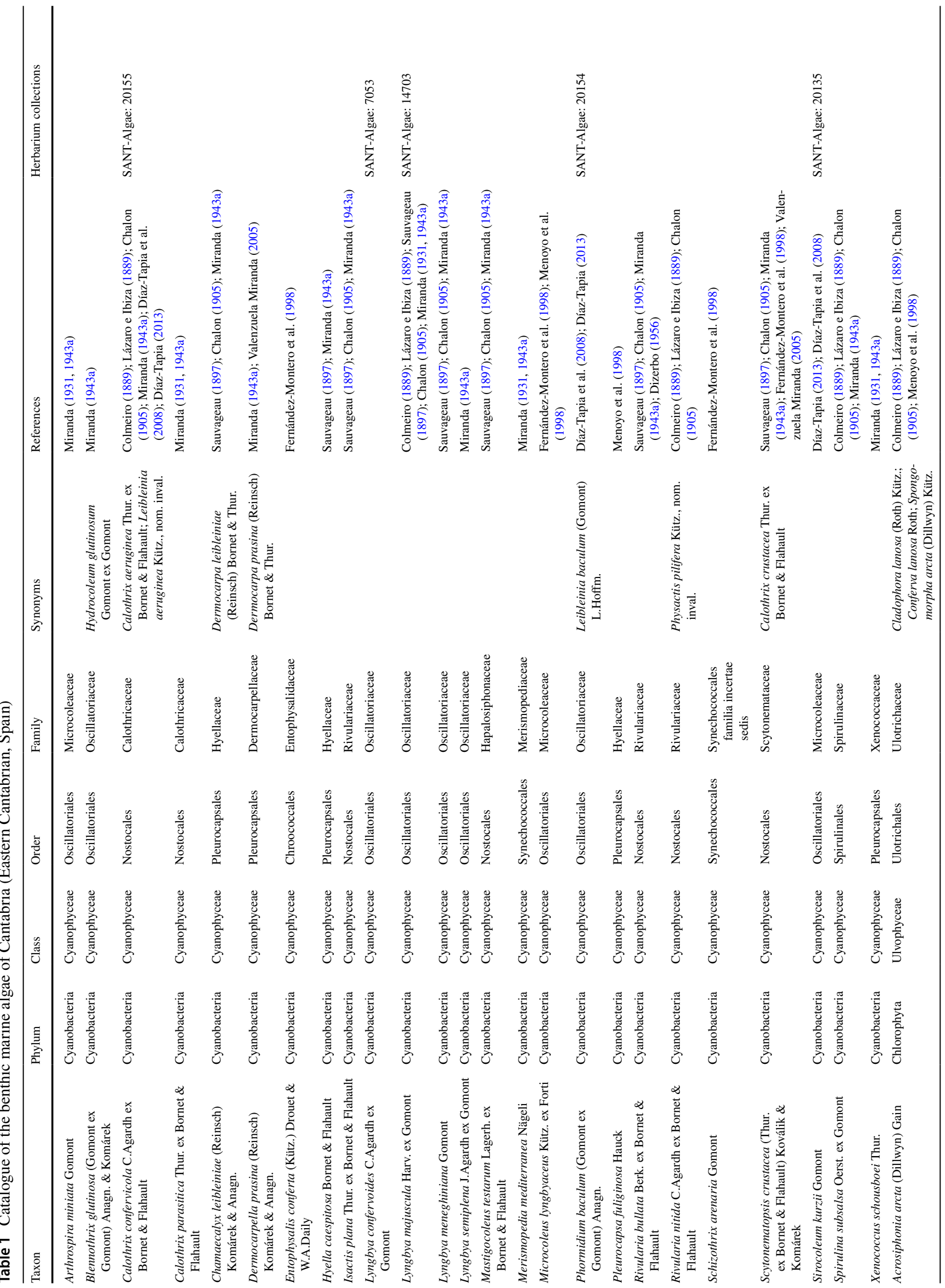




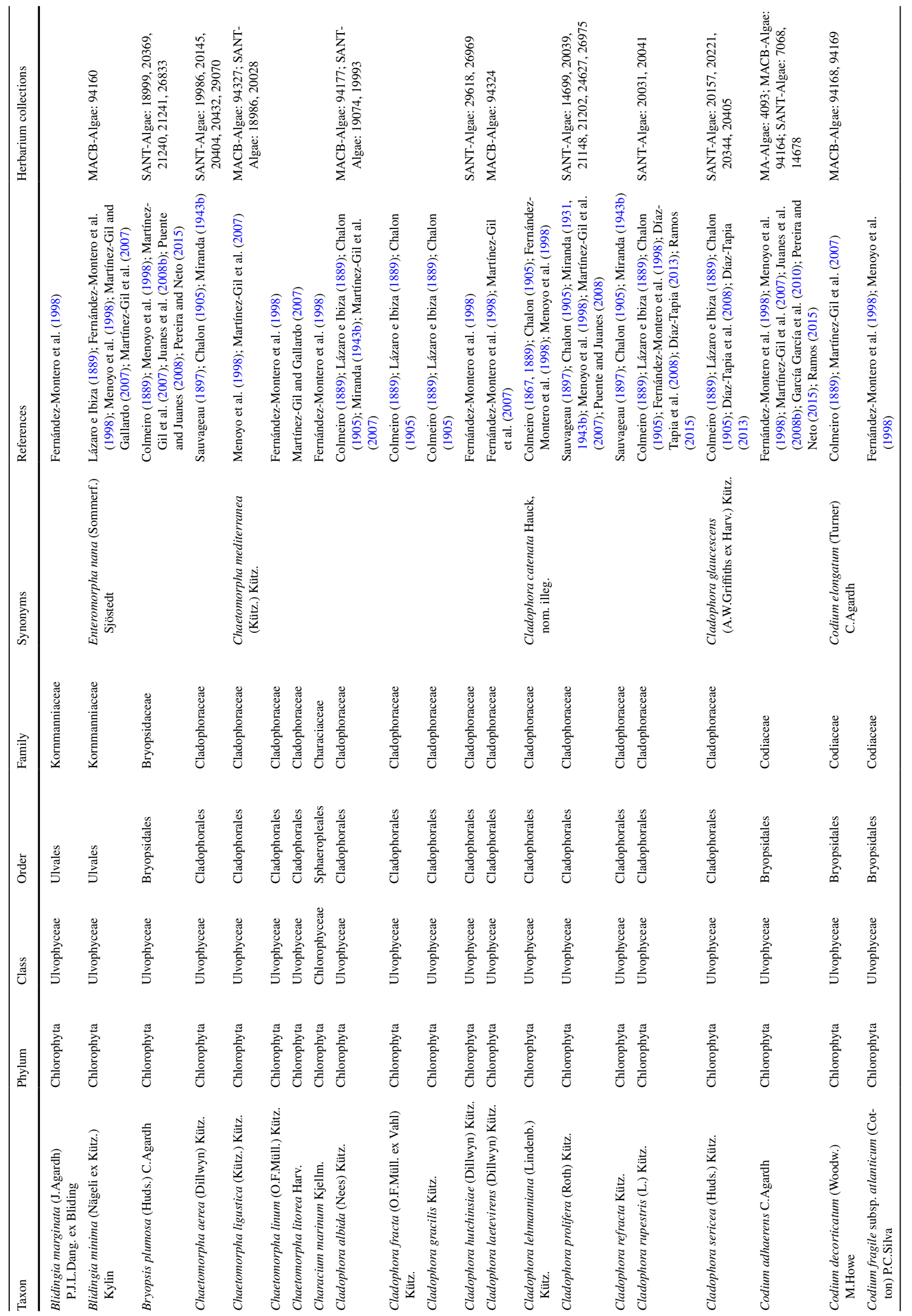




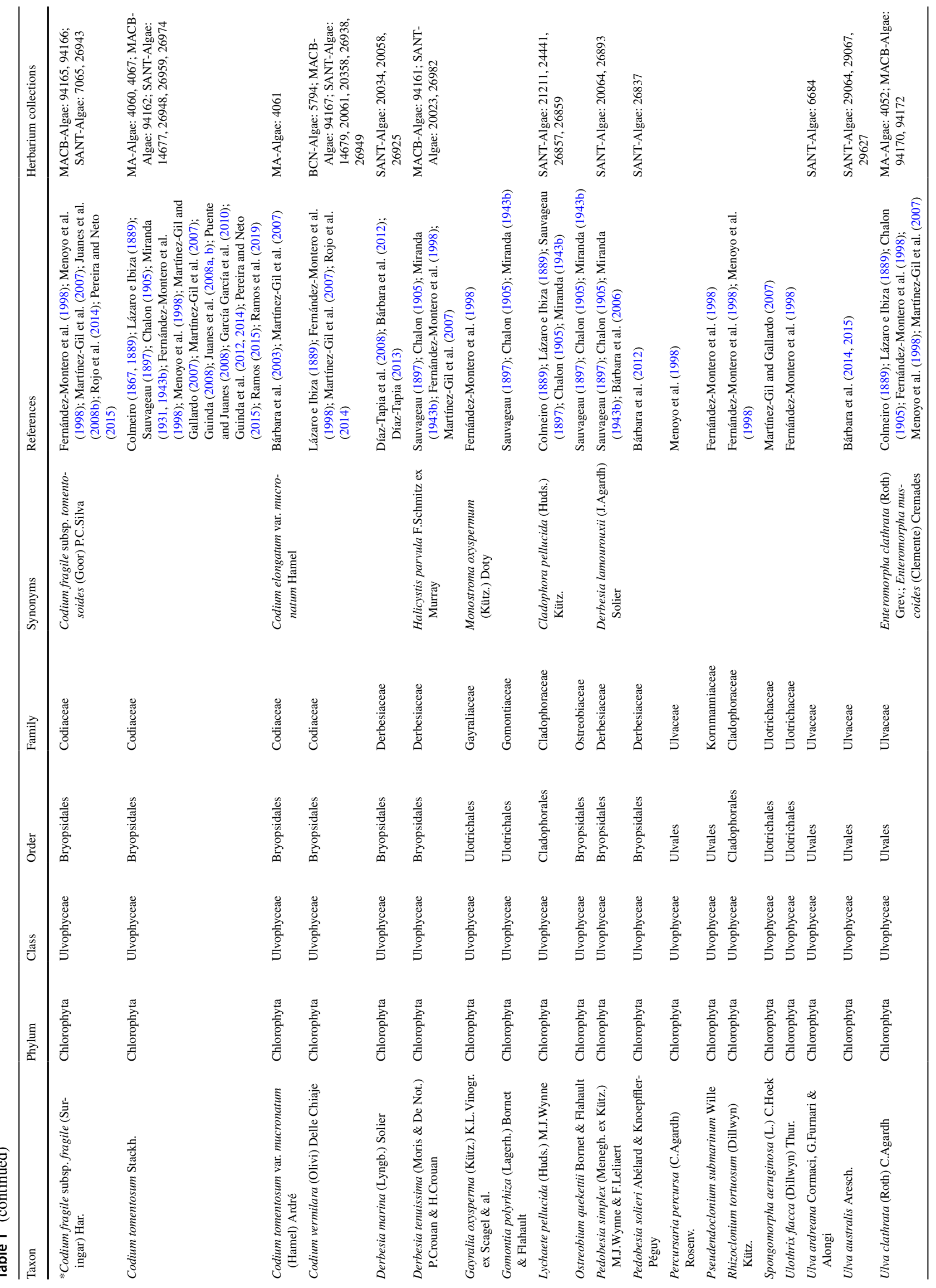




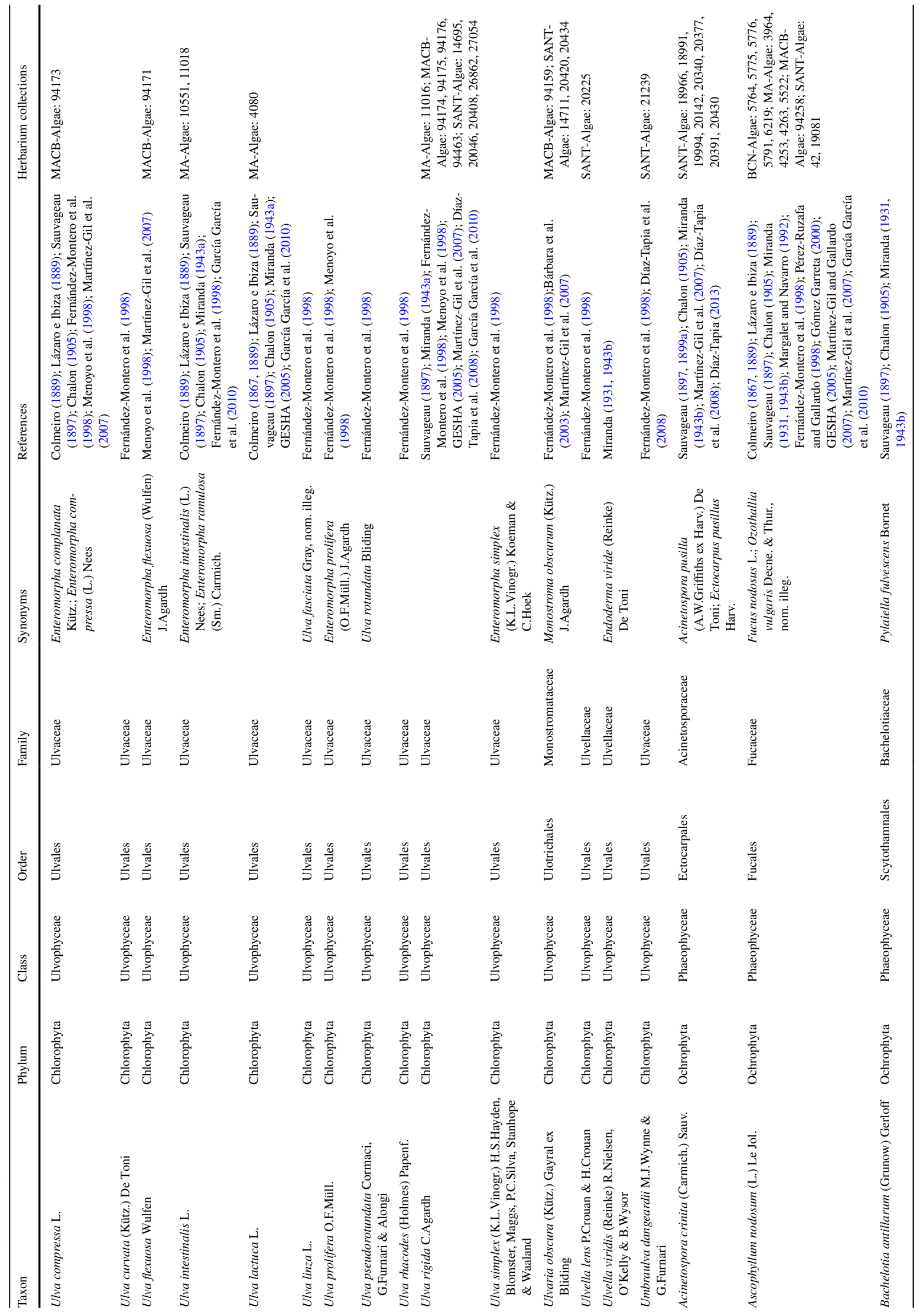




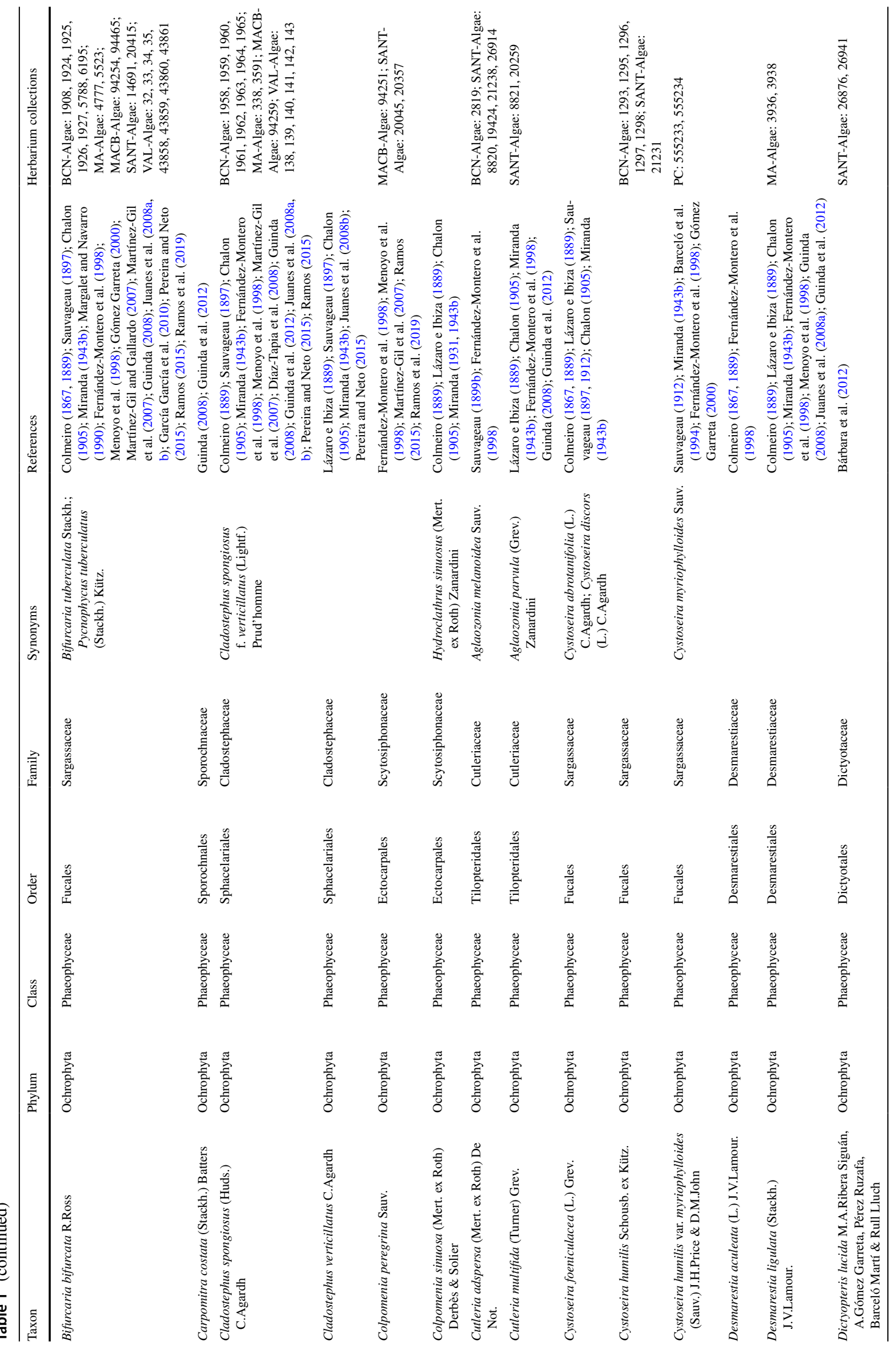




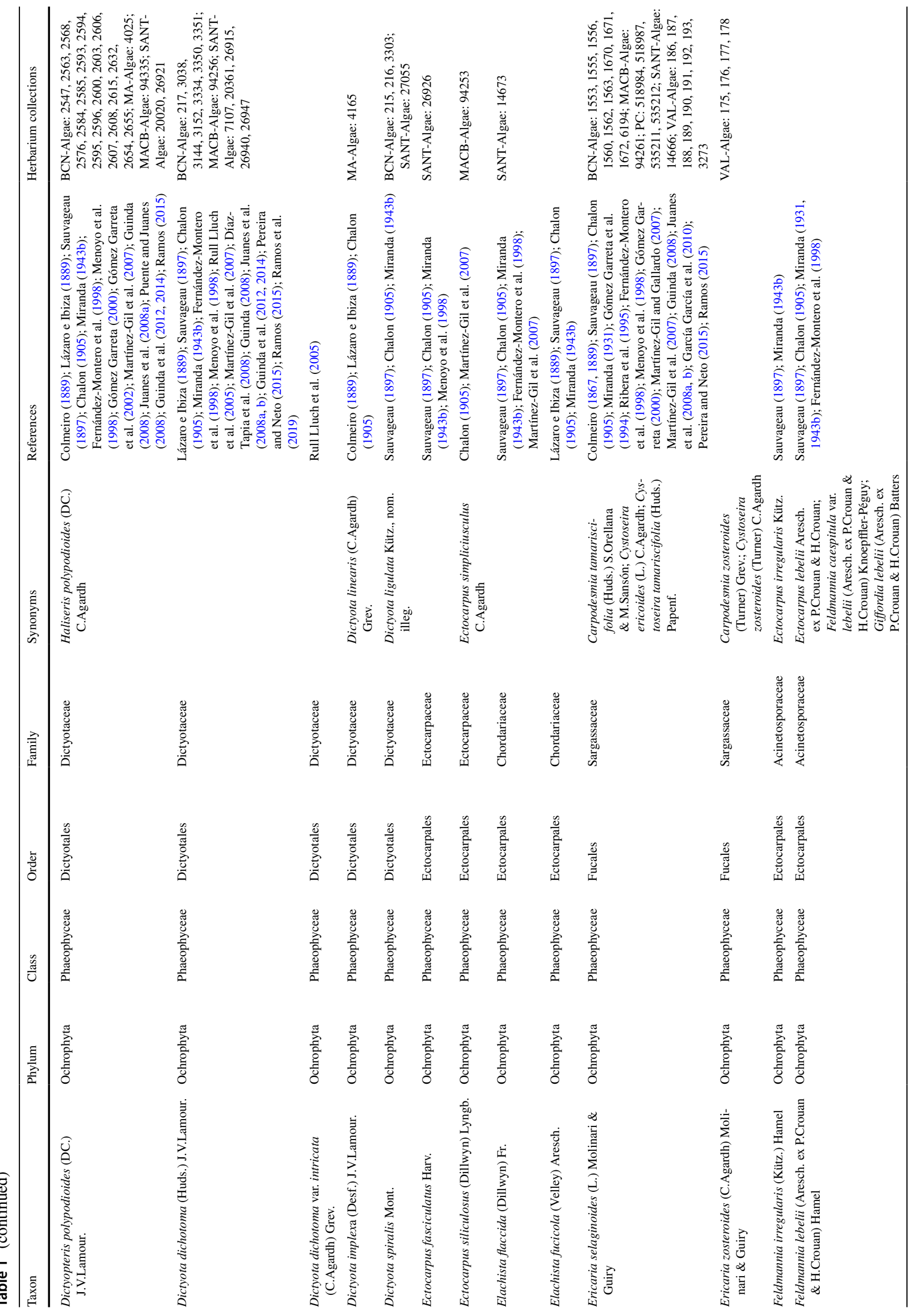




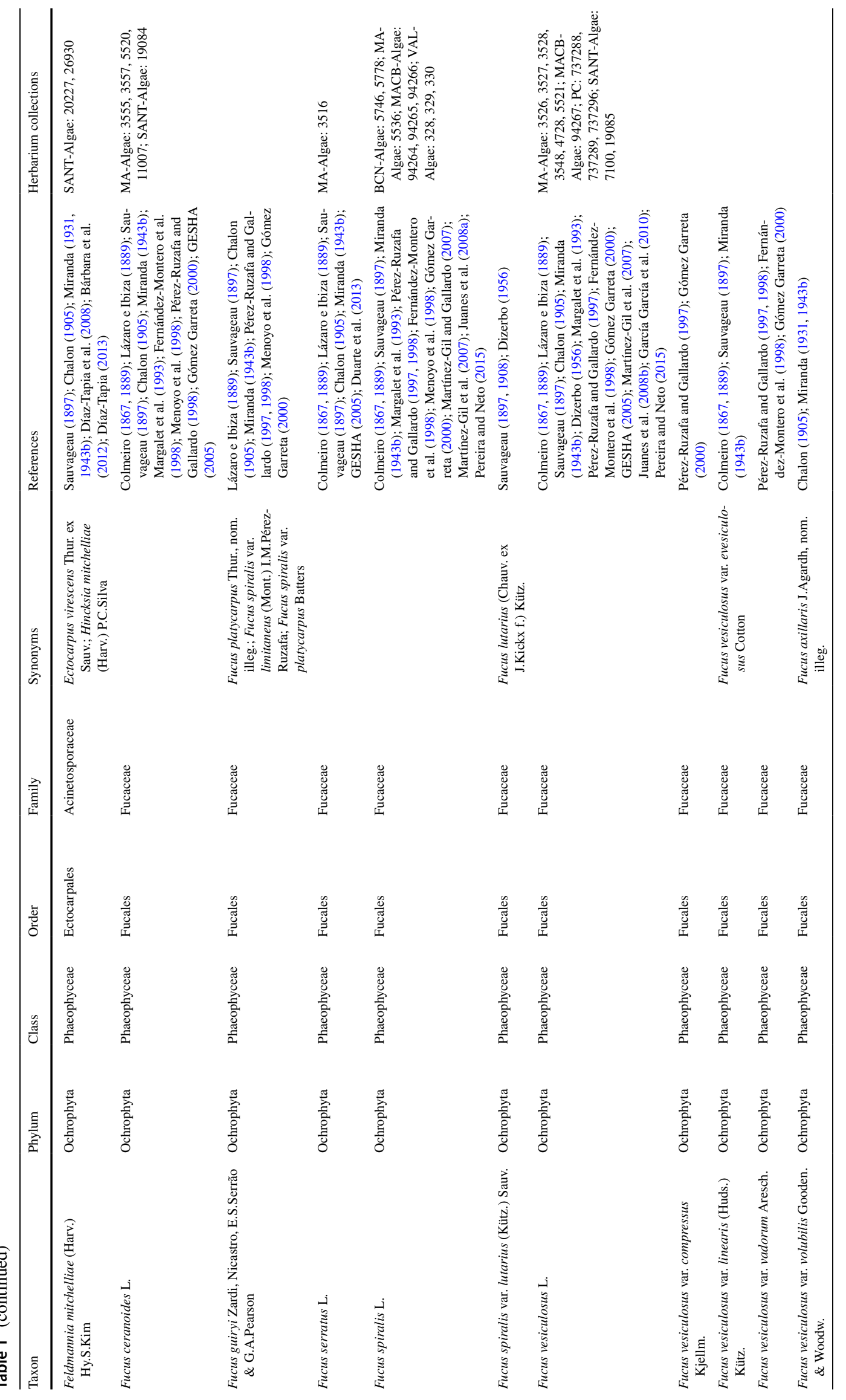




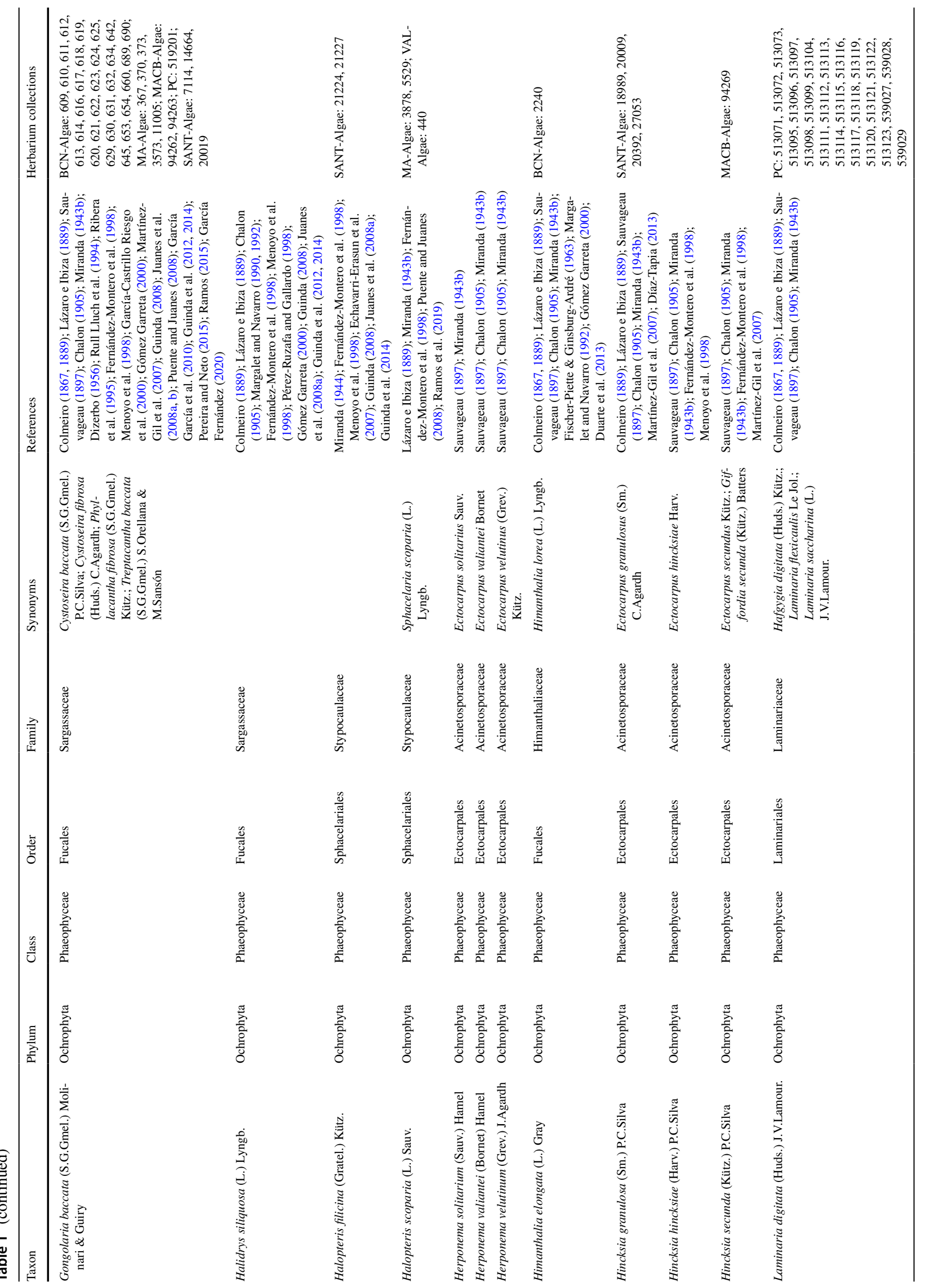




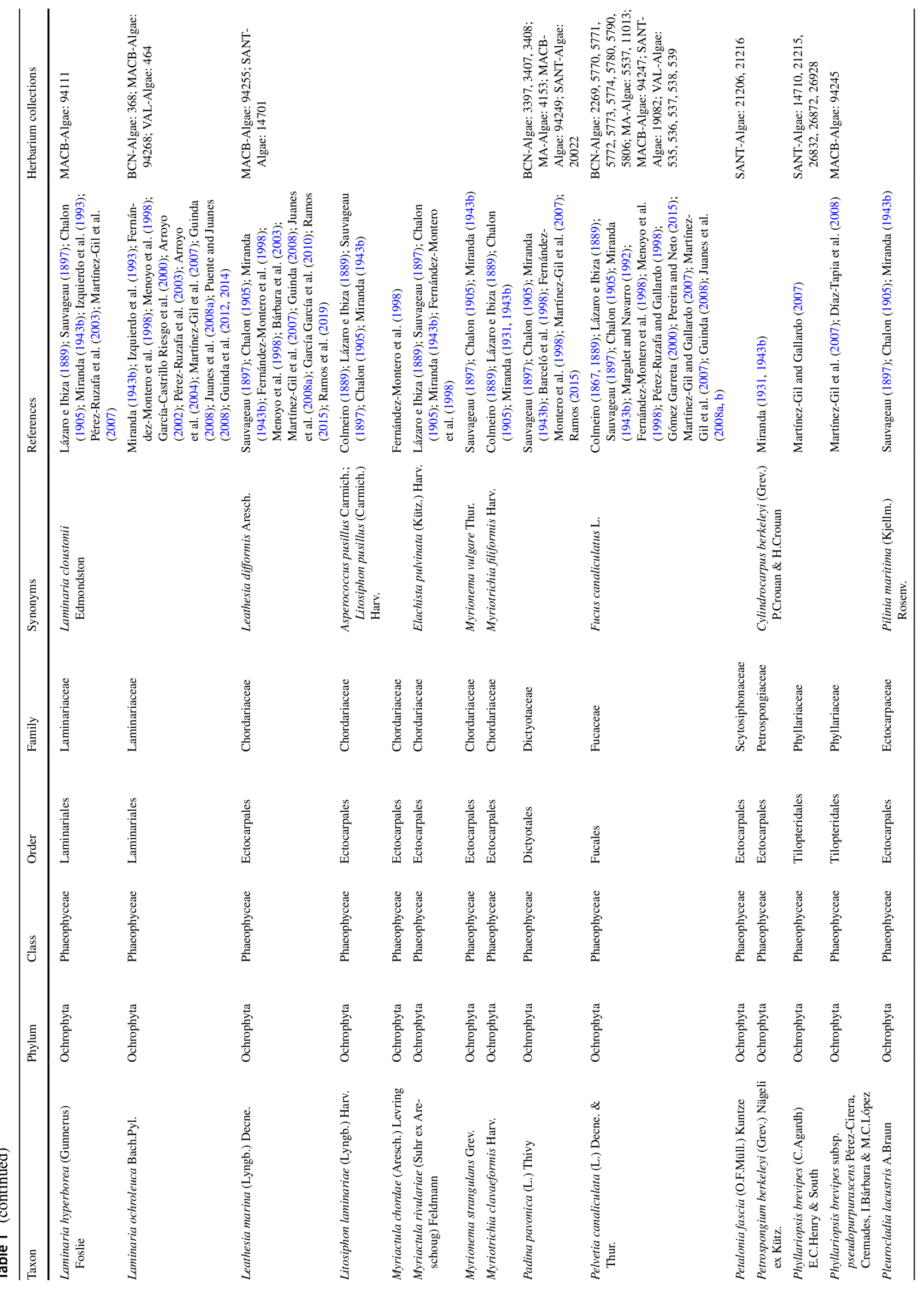




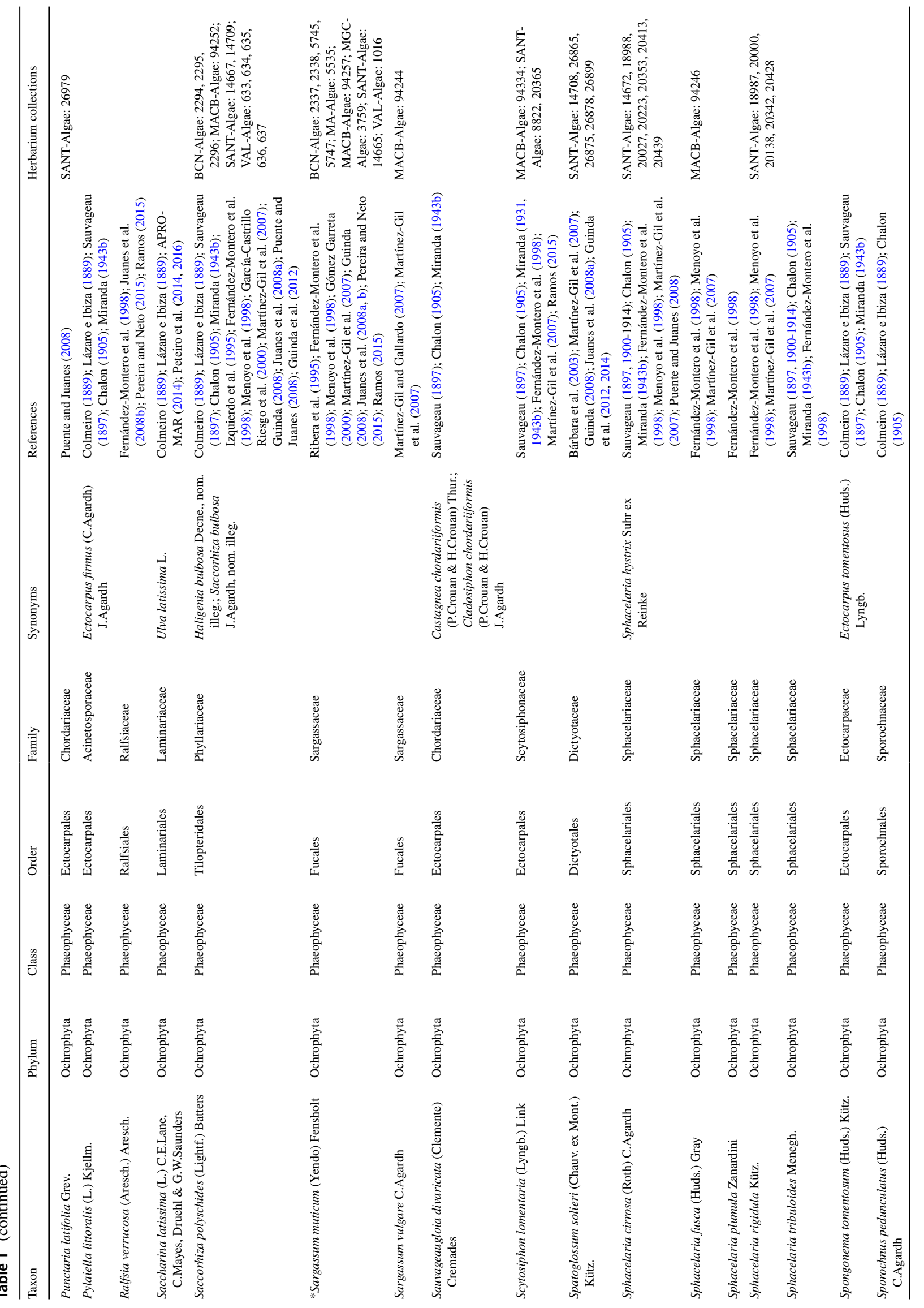




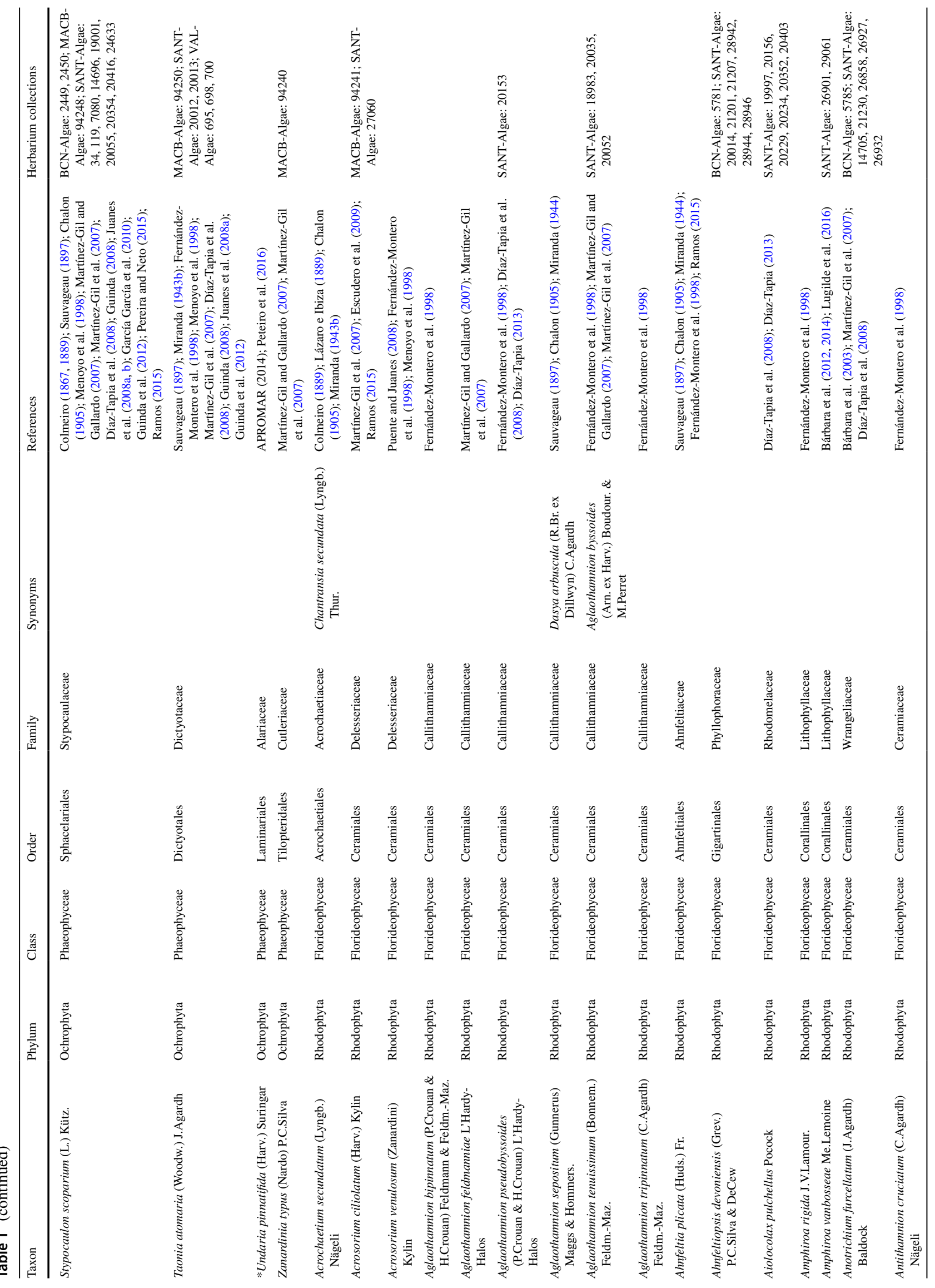




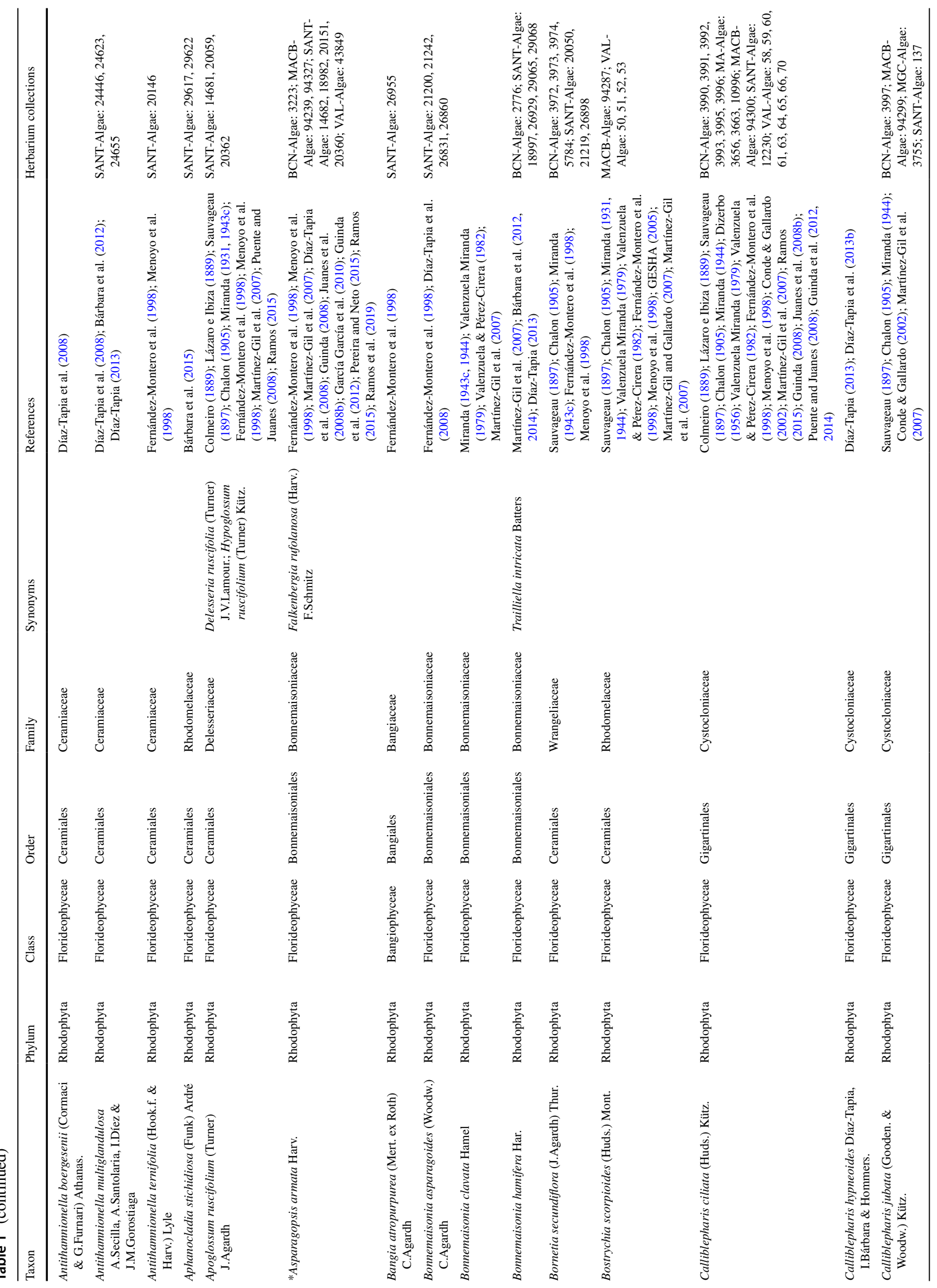




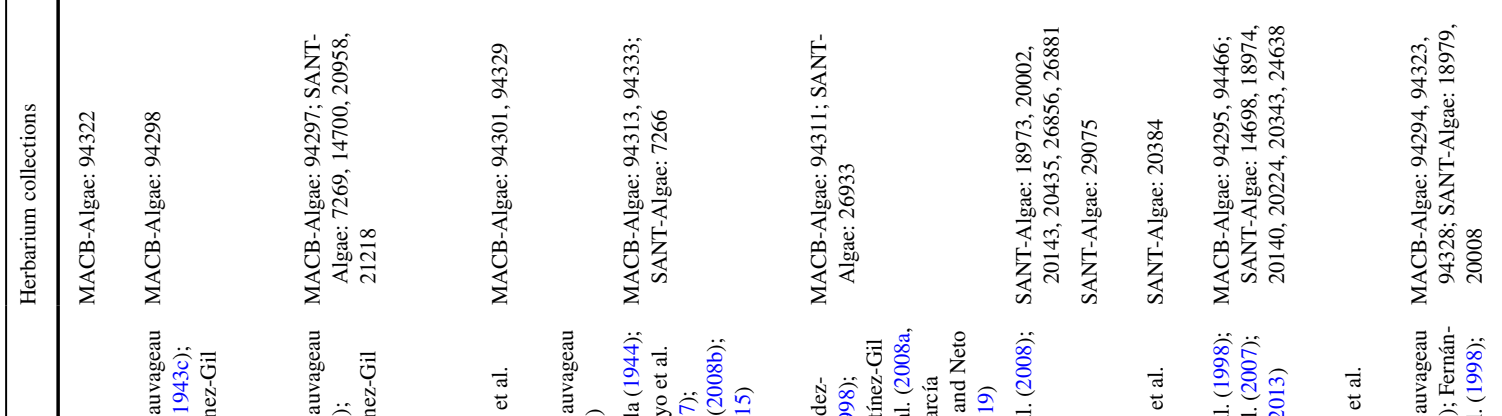

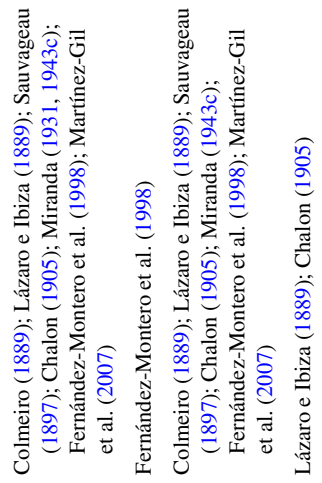

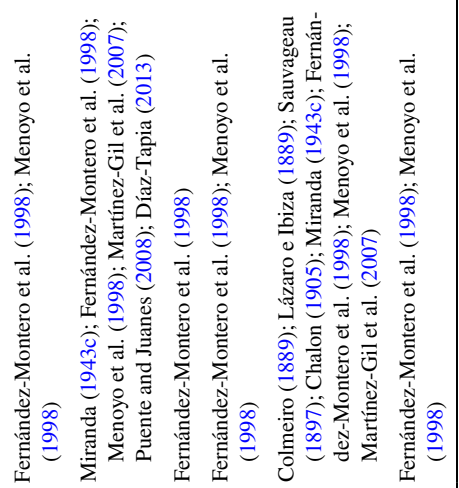
$\int$

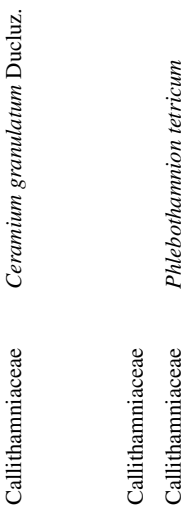

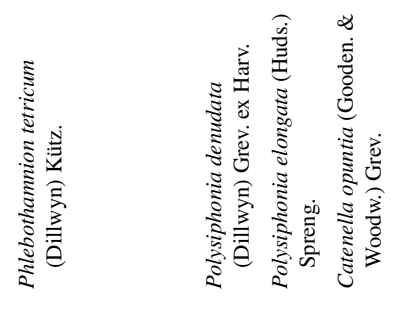

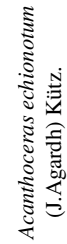

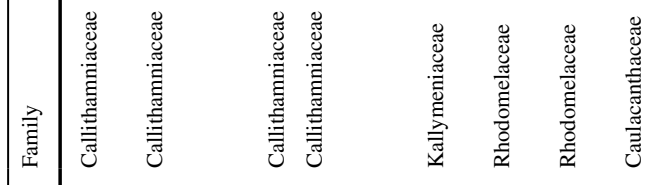

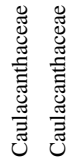

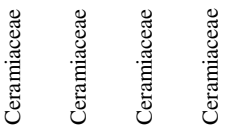

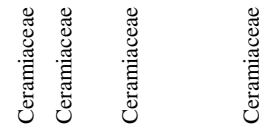

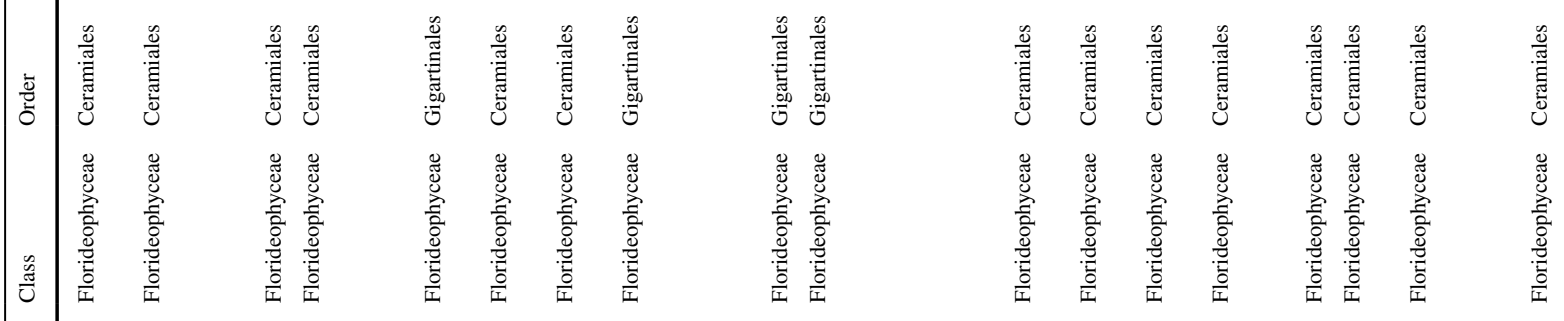

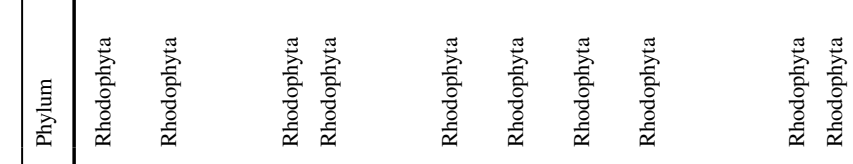

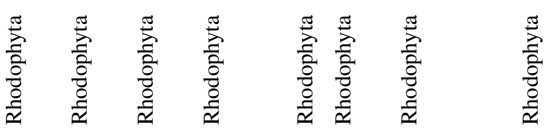

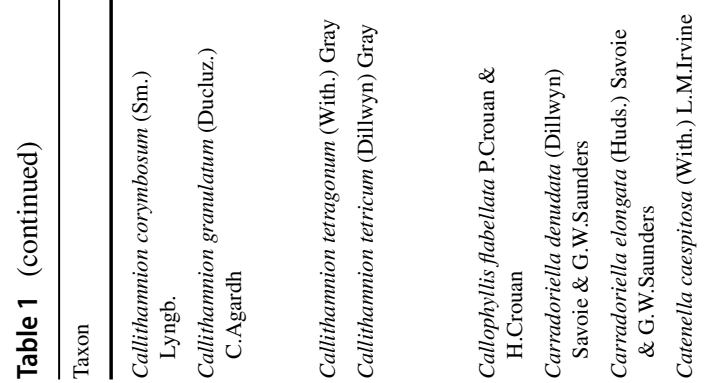

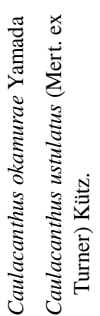

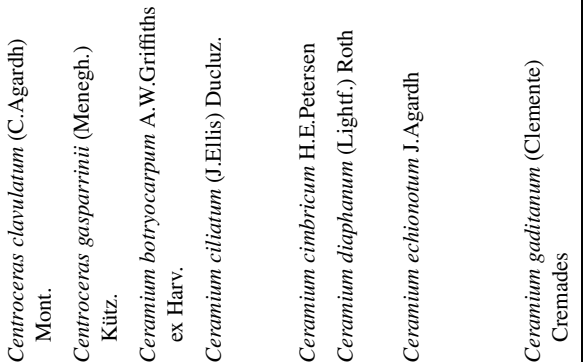




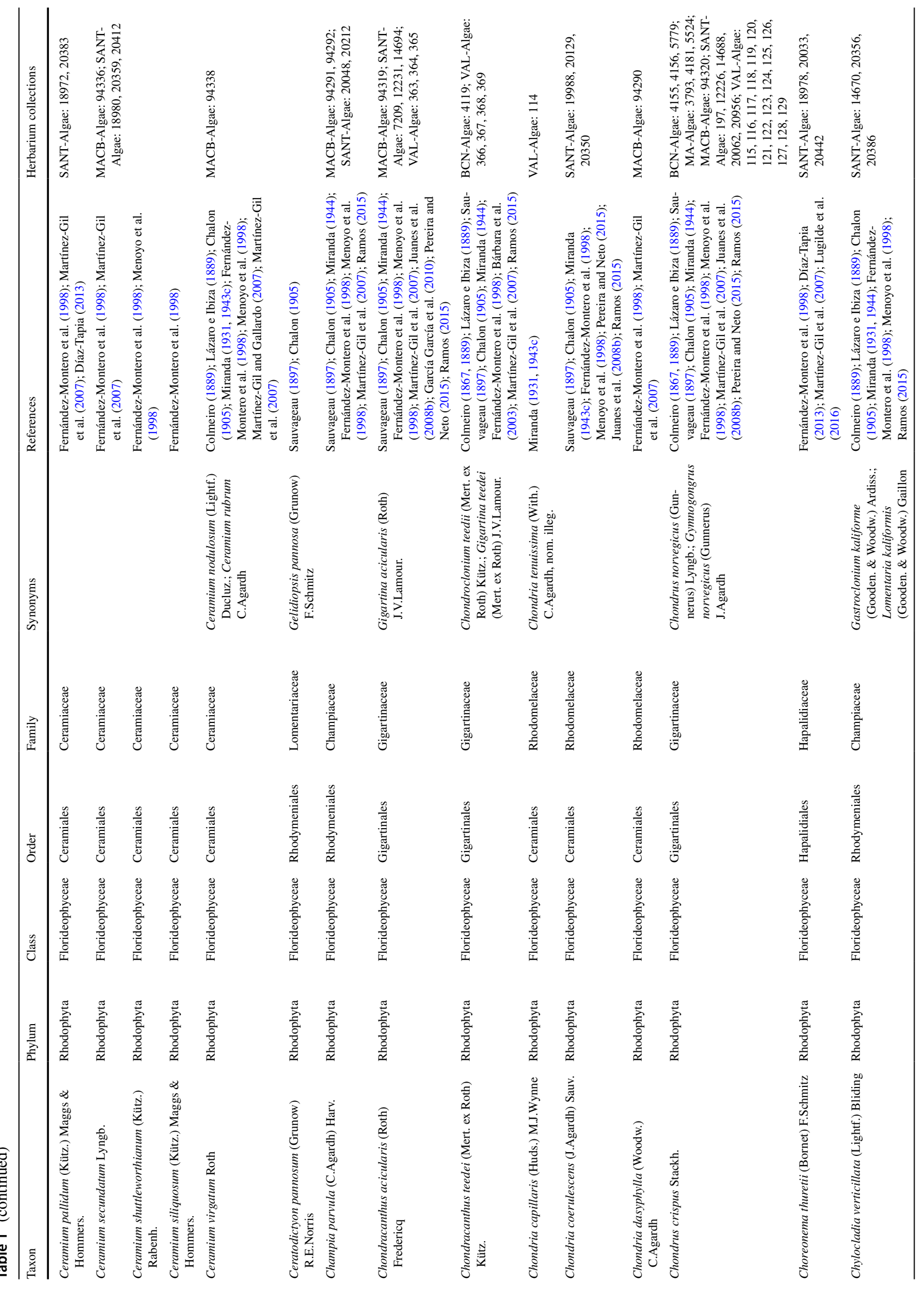




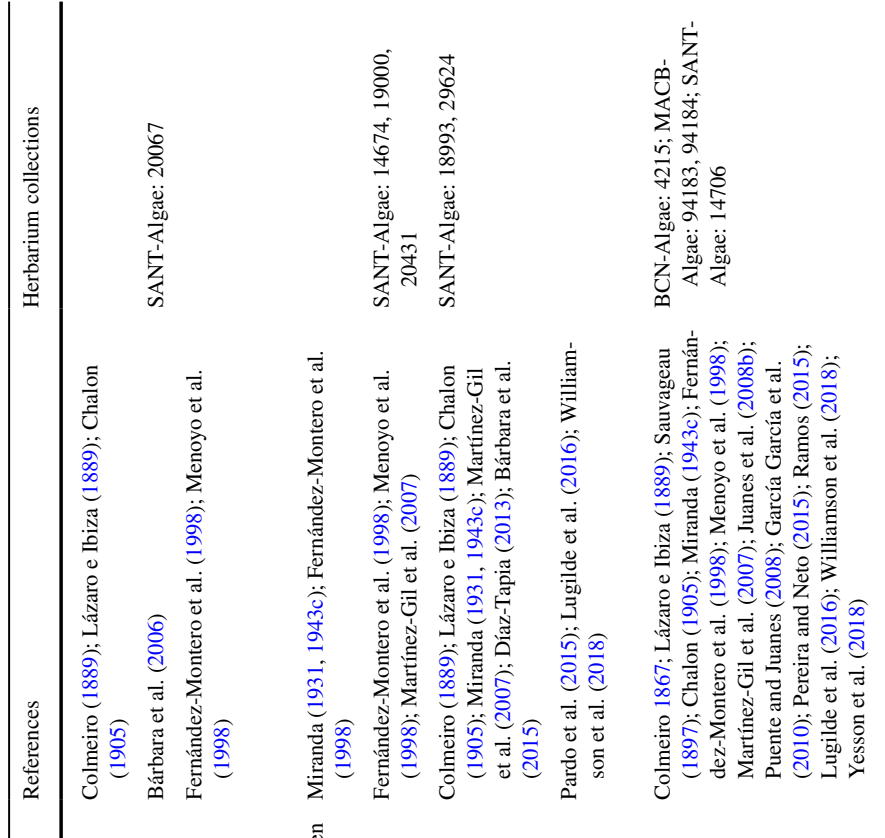

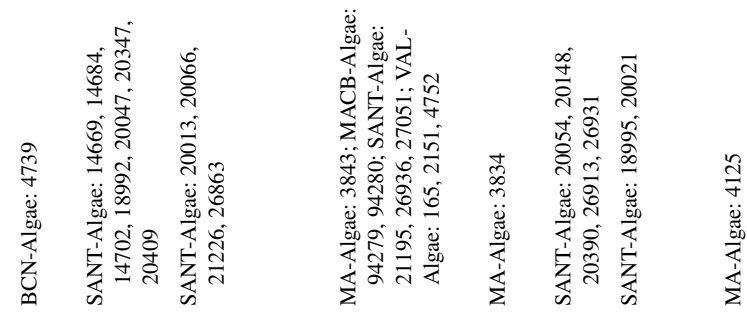

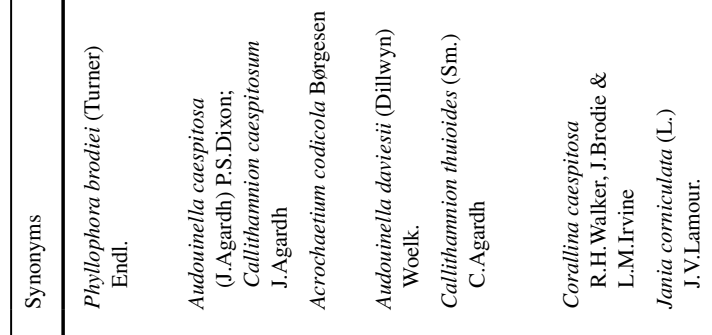
害

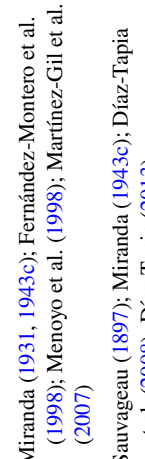

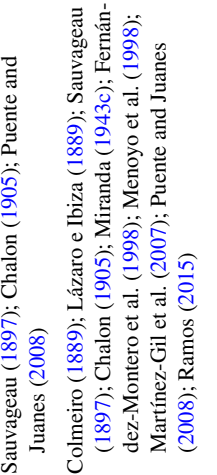

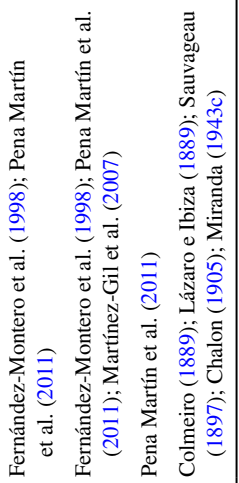
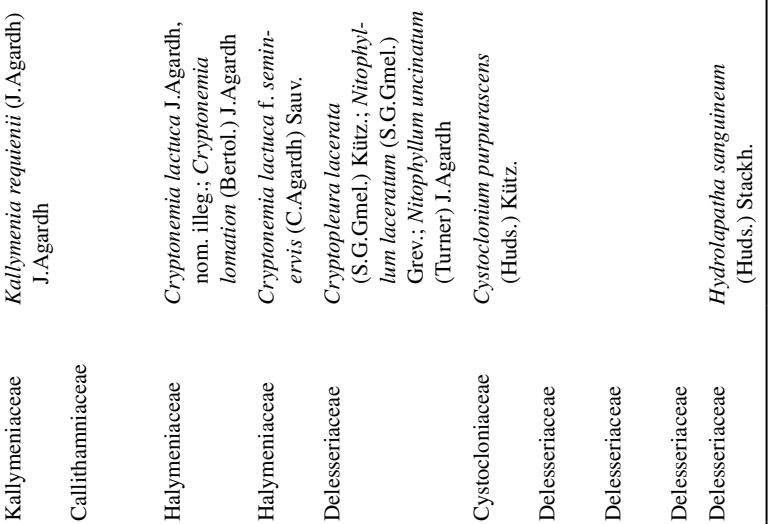

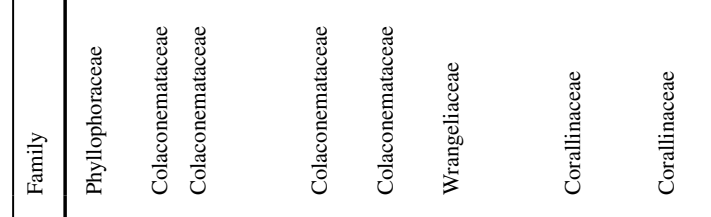

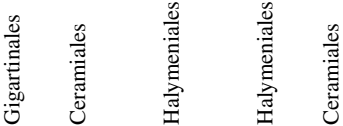

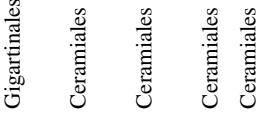

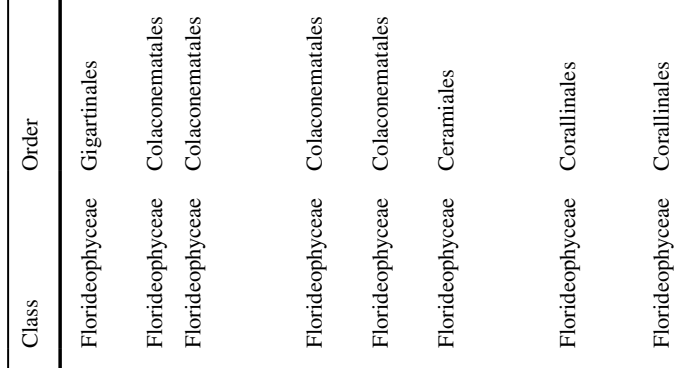

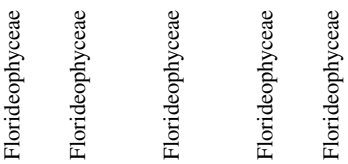

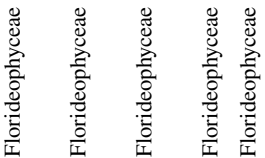

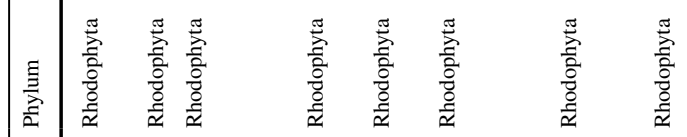

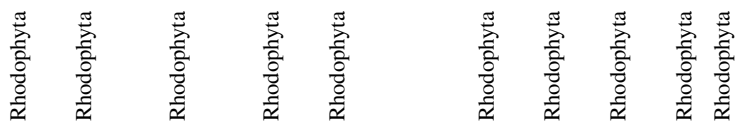

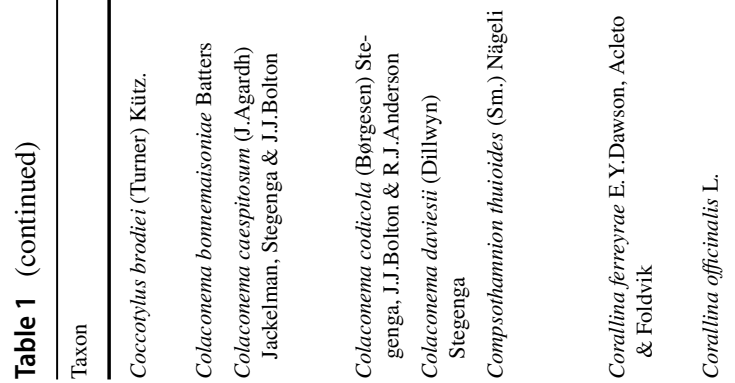

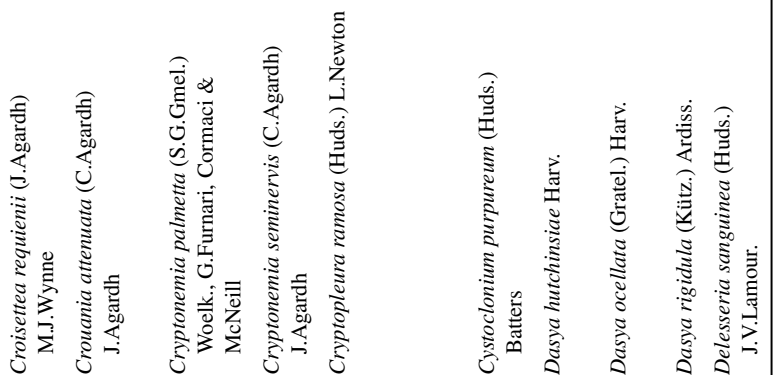




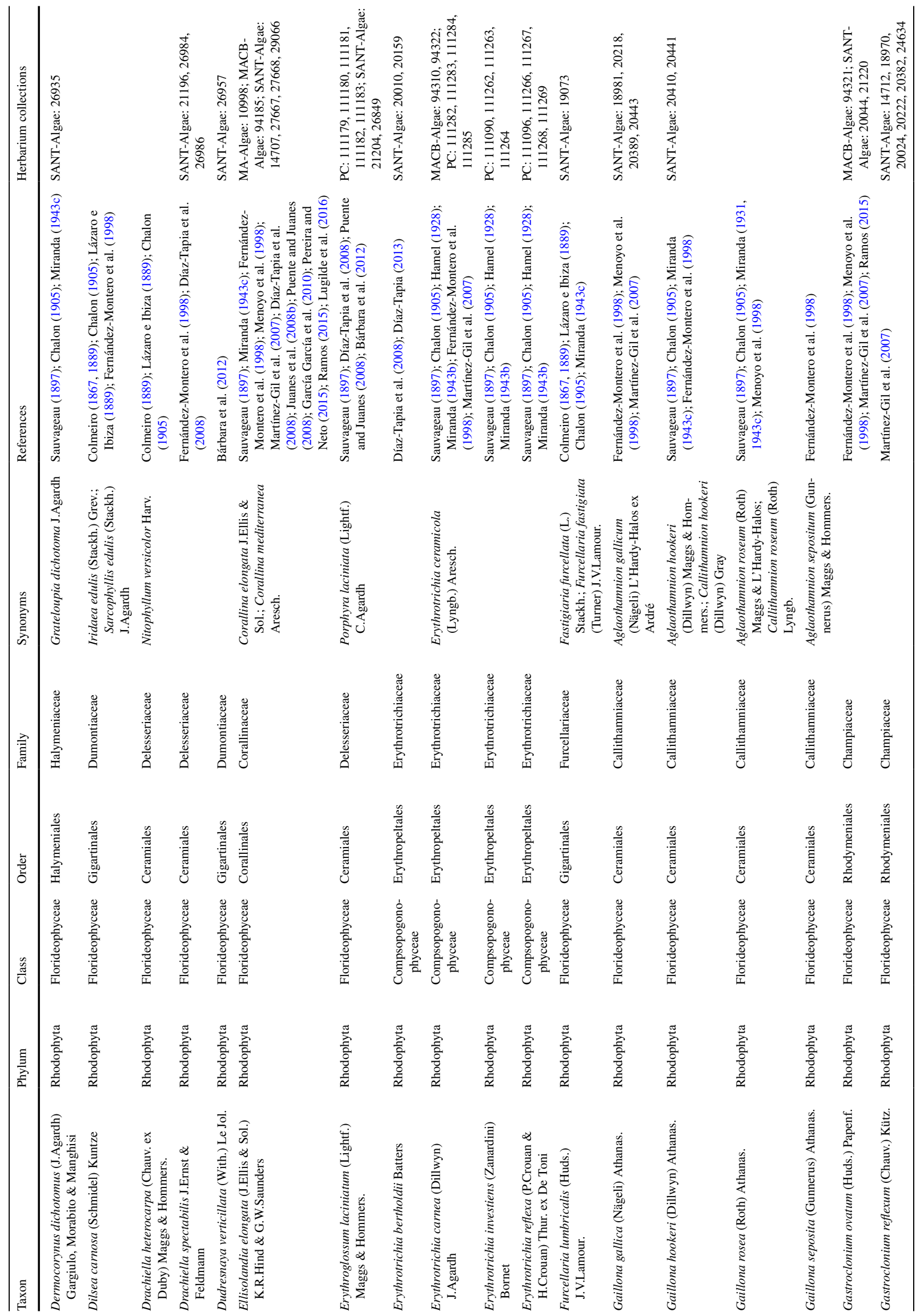




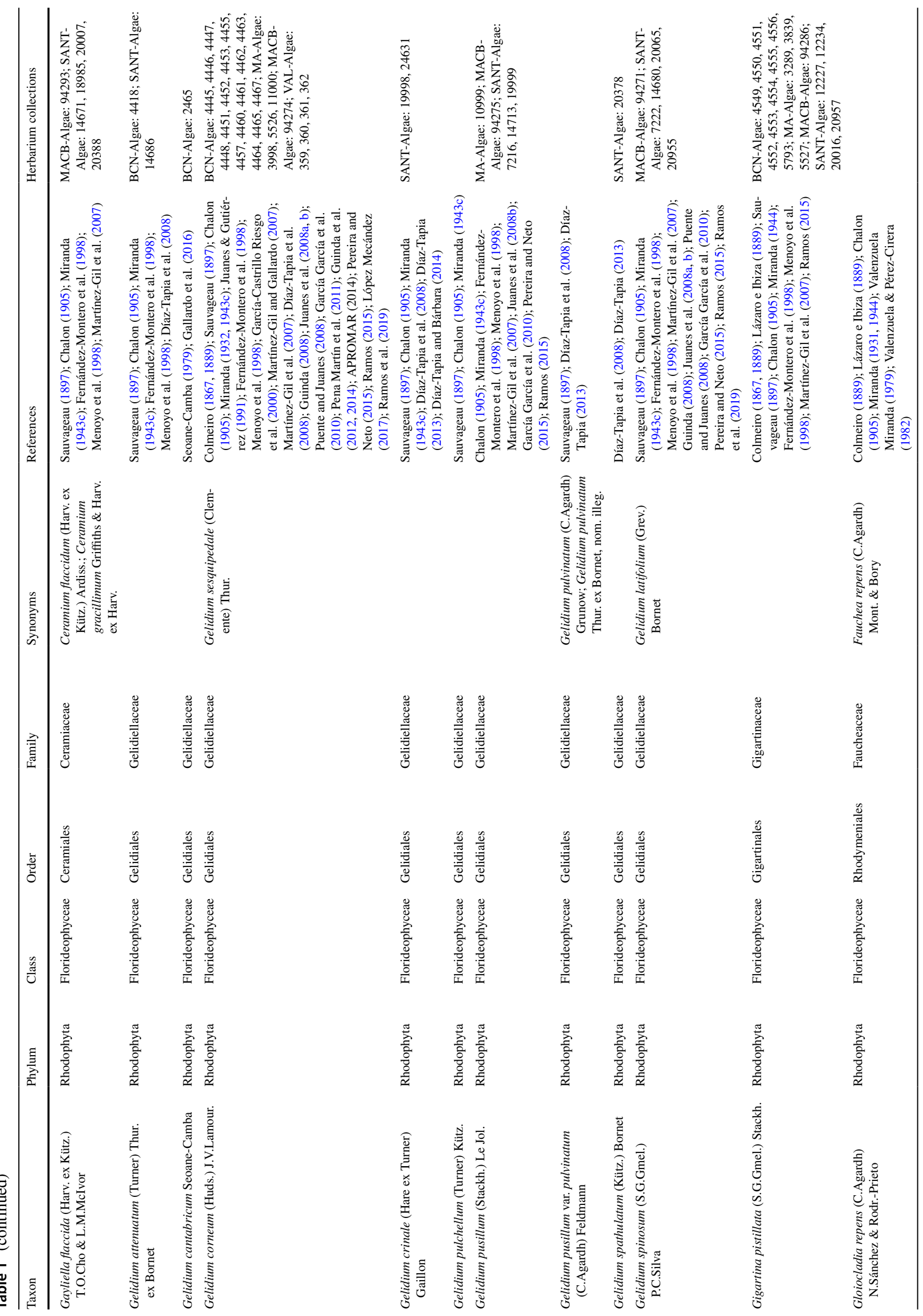




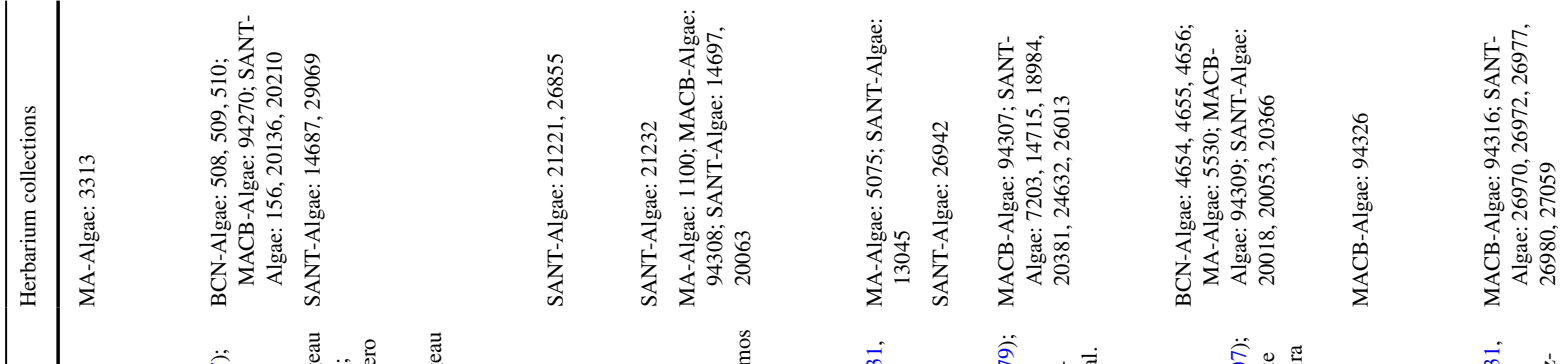

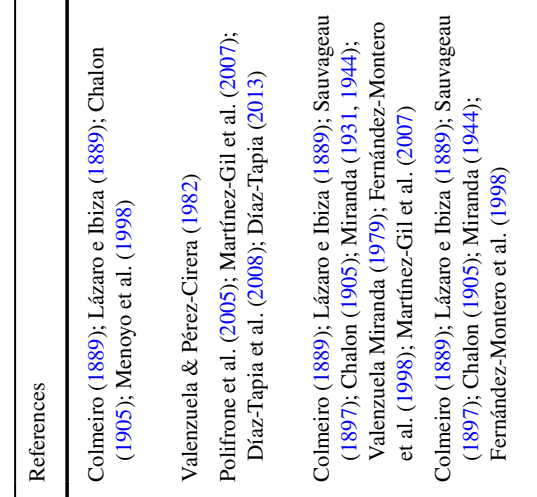

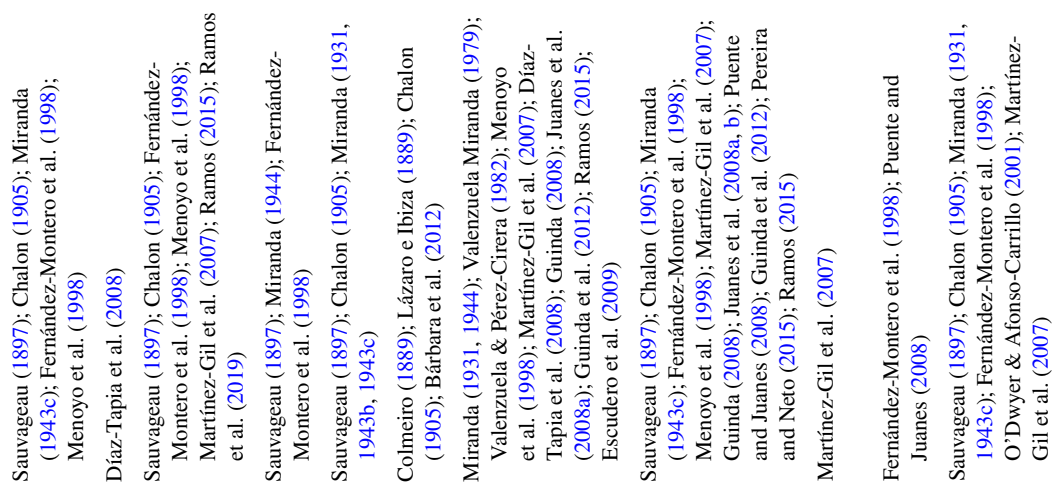

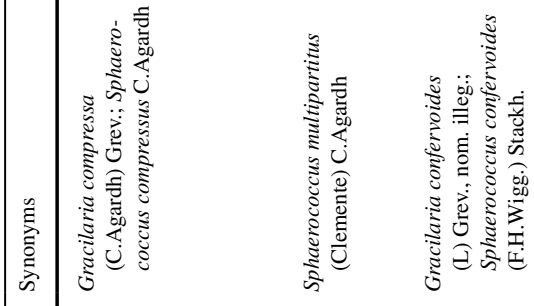

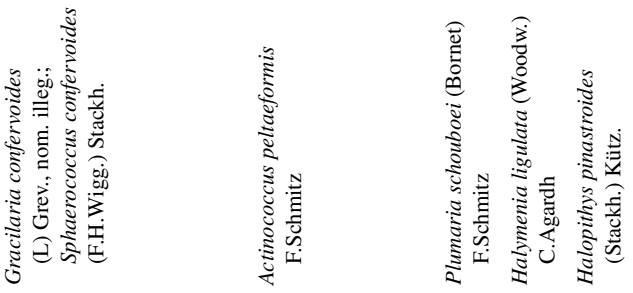
竞

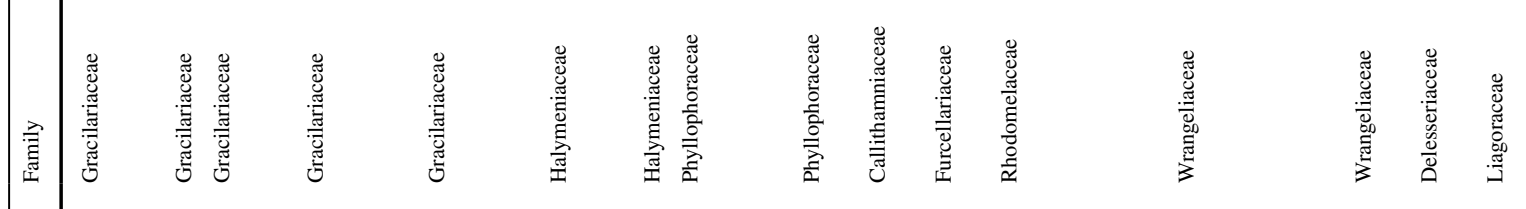

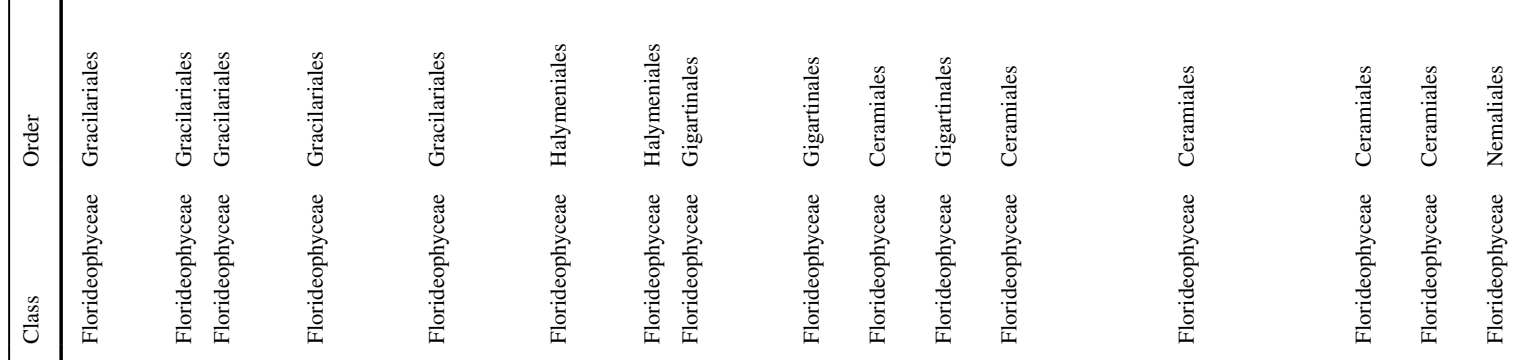

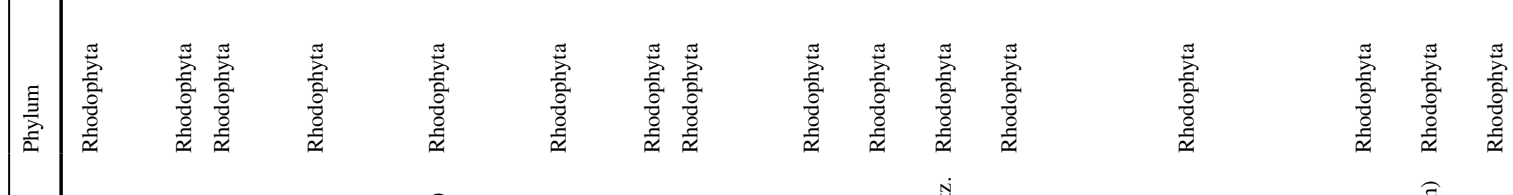

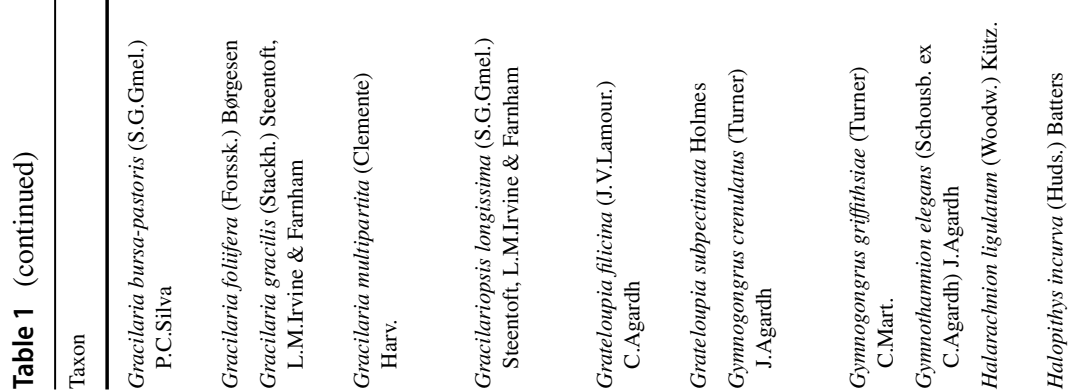

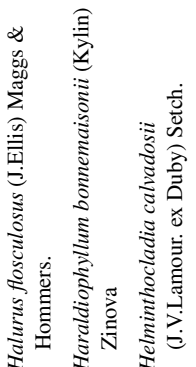




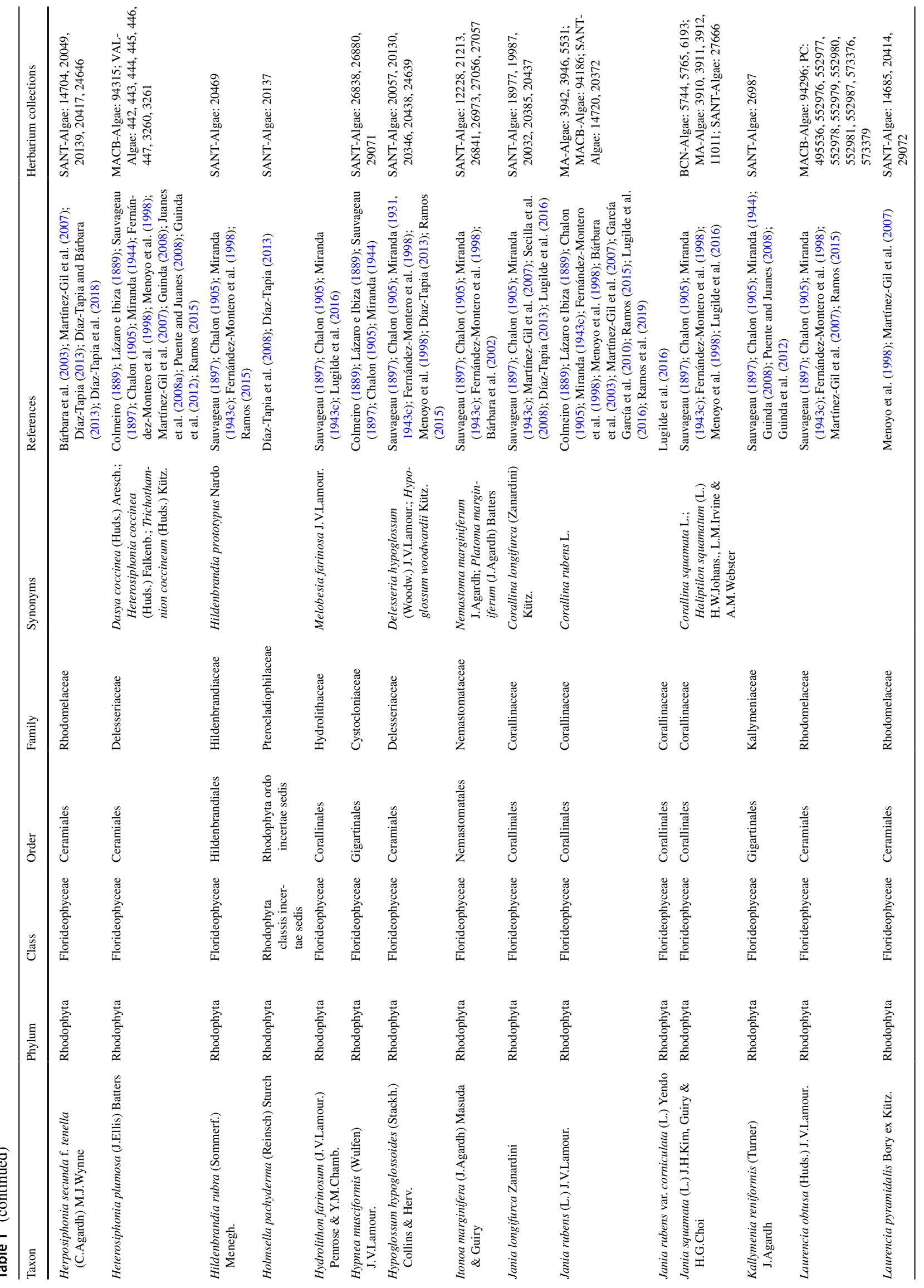




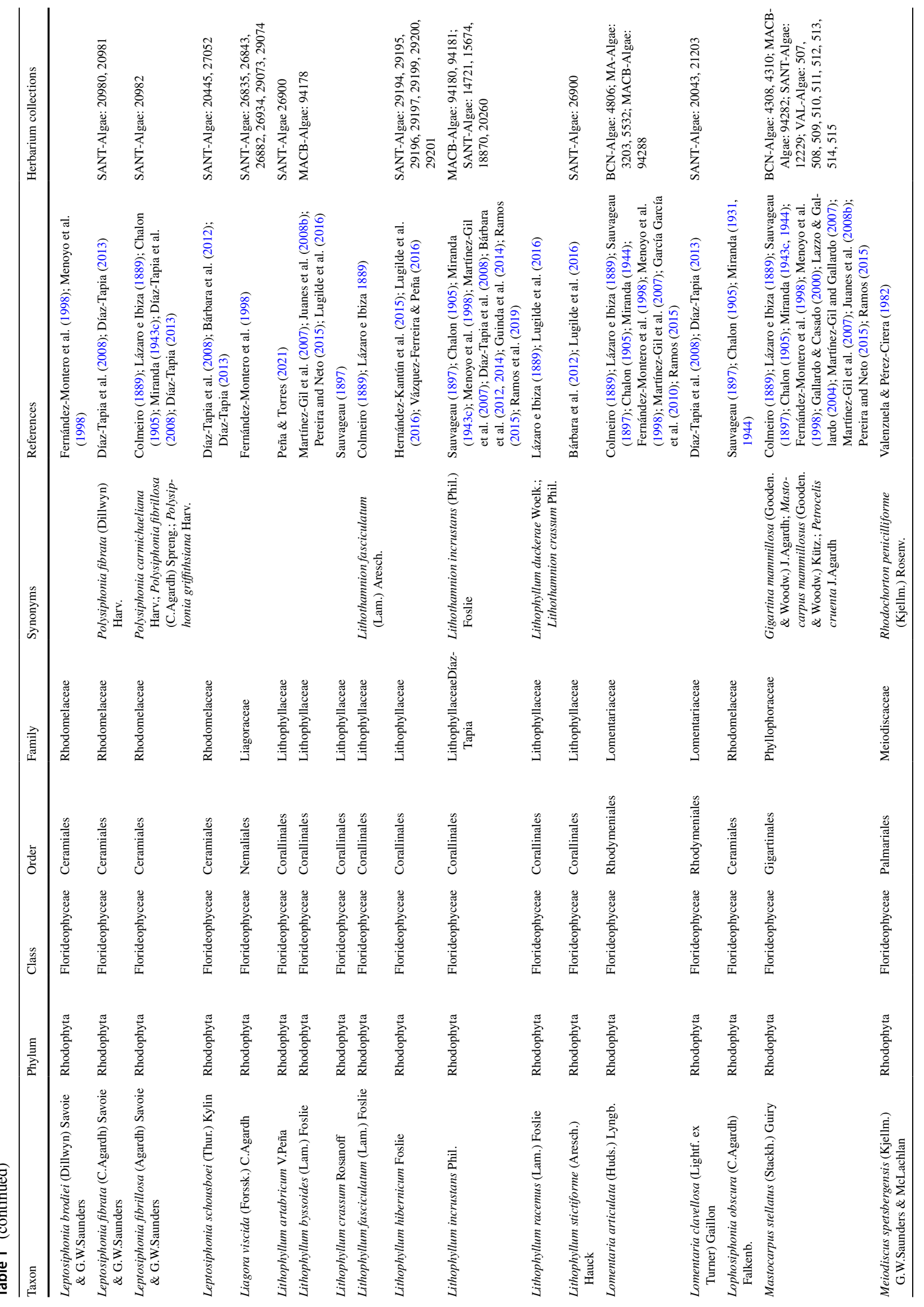




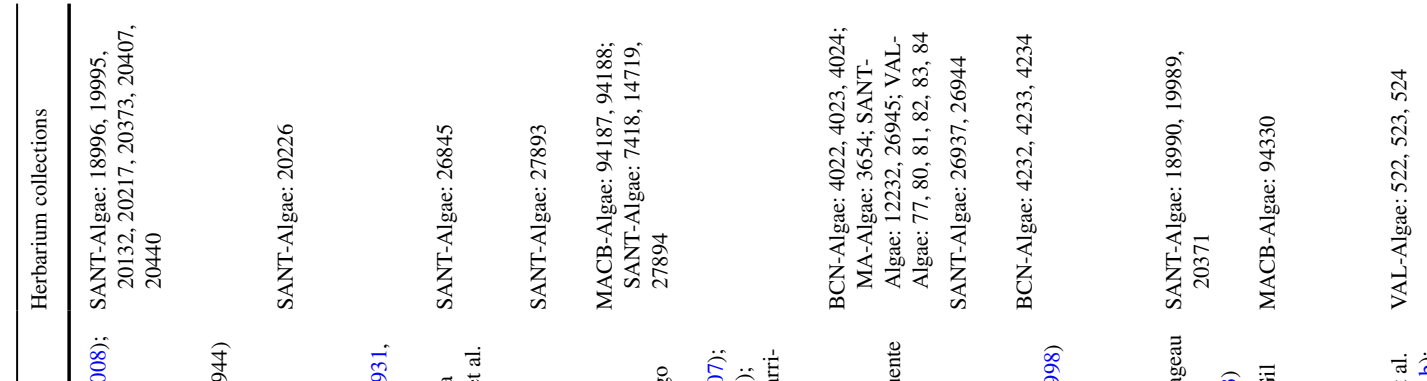

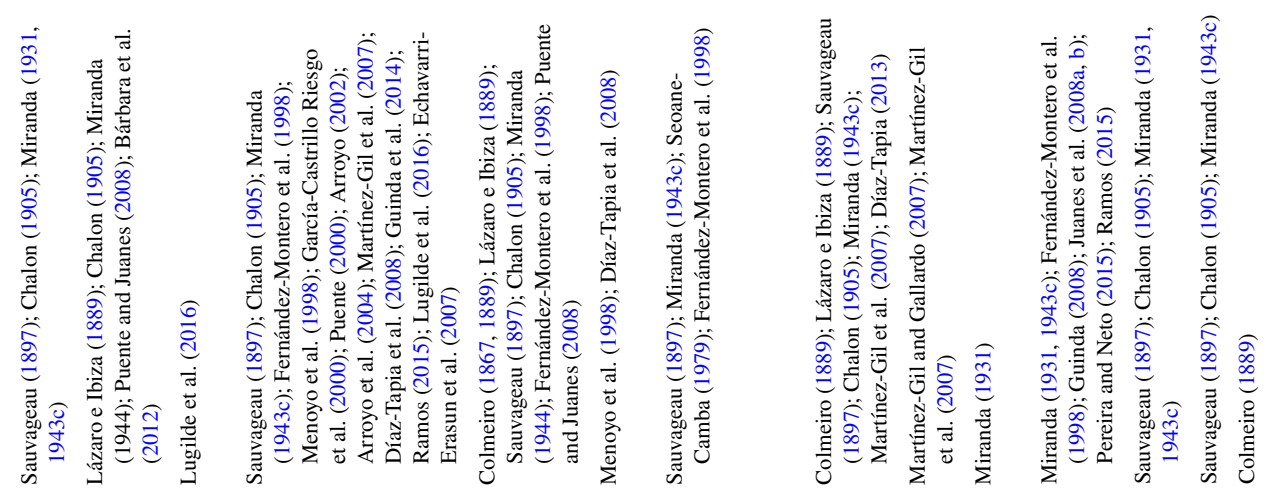

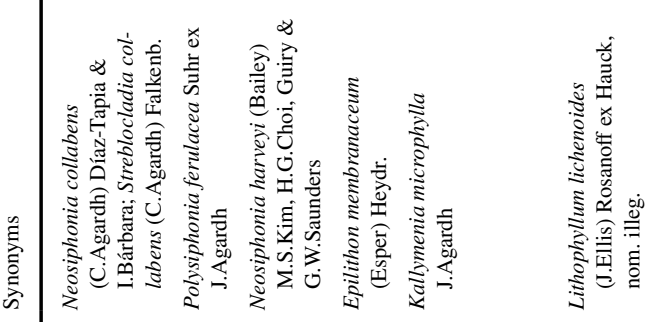

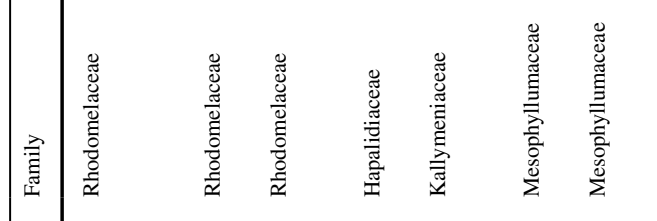

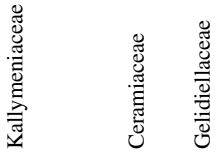

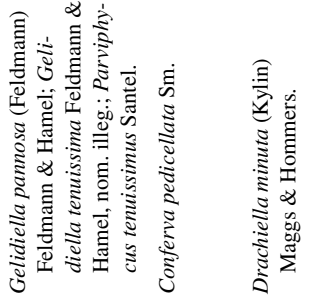

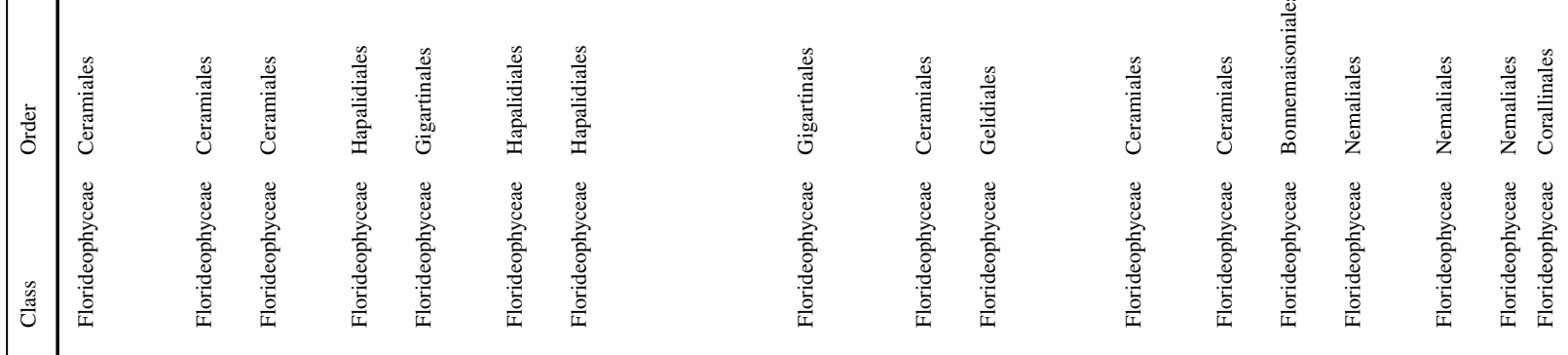

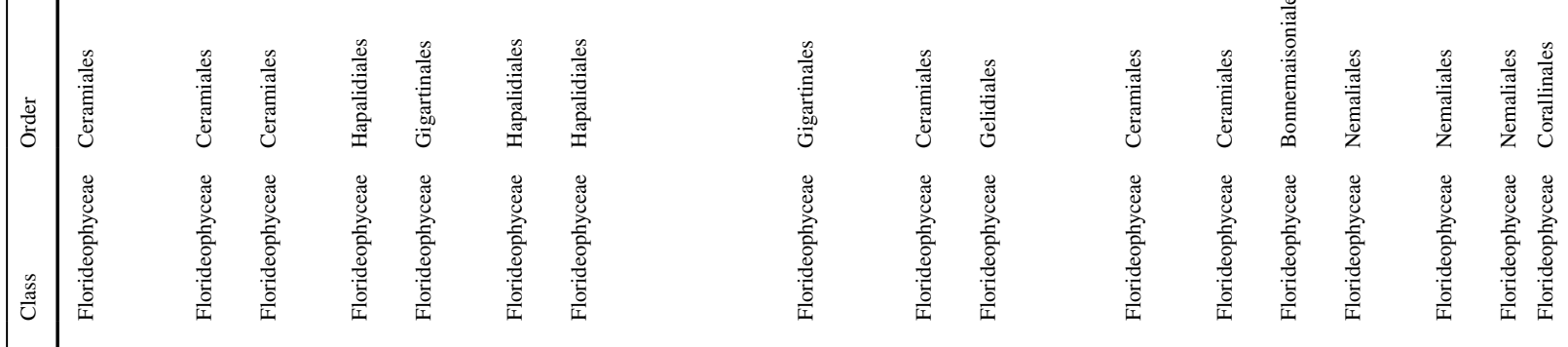

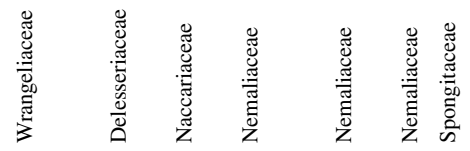

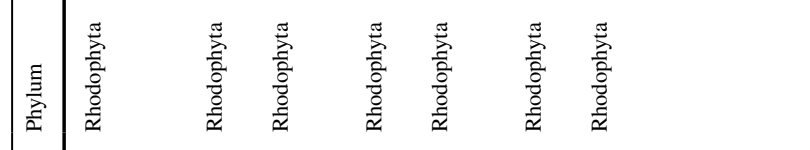

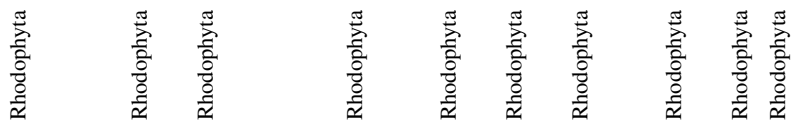

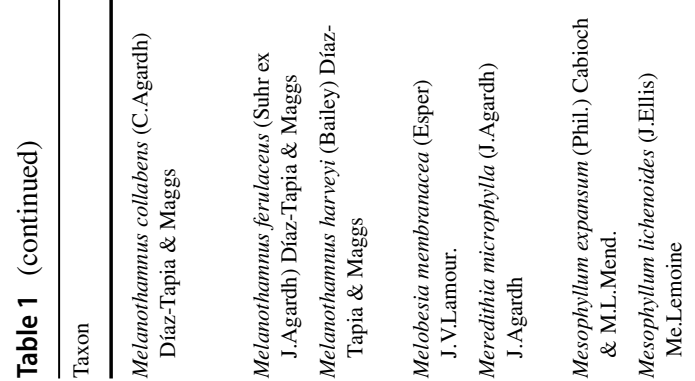

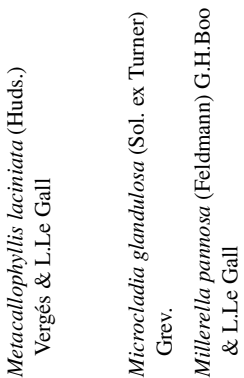

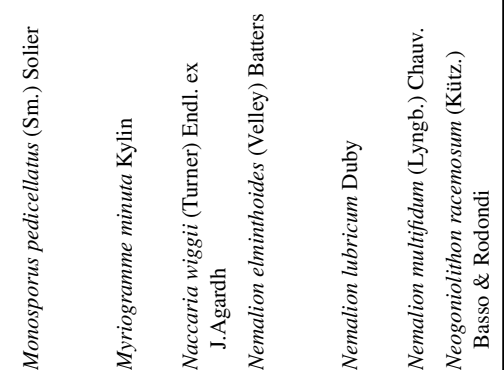




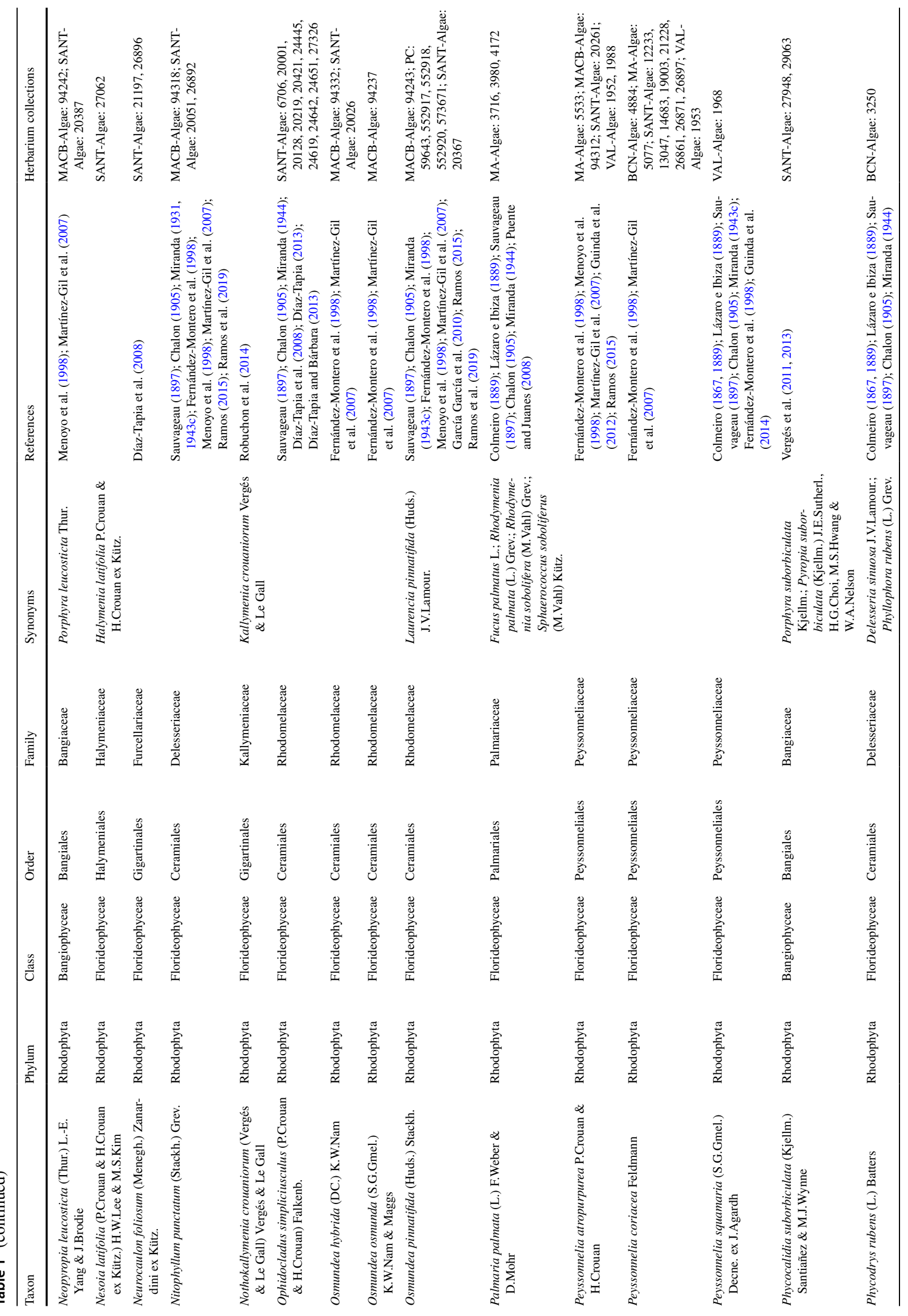




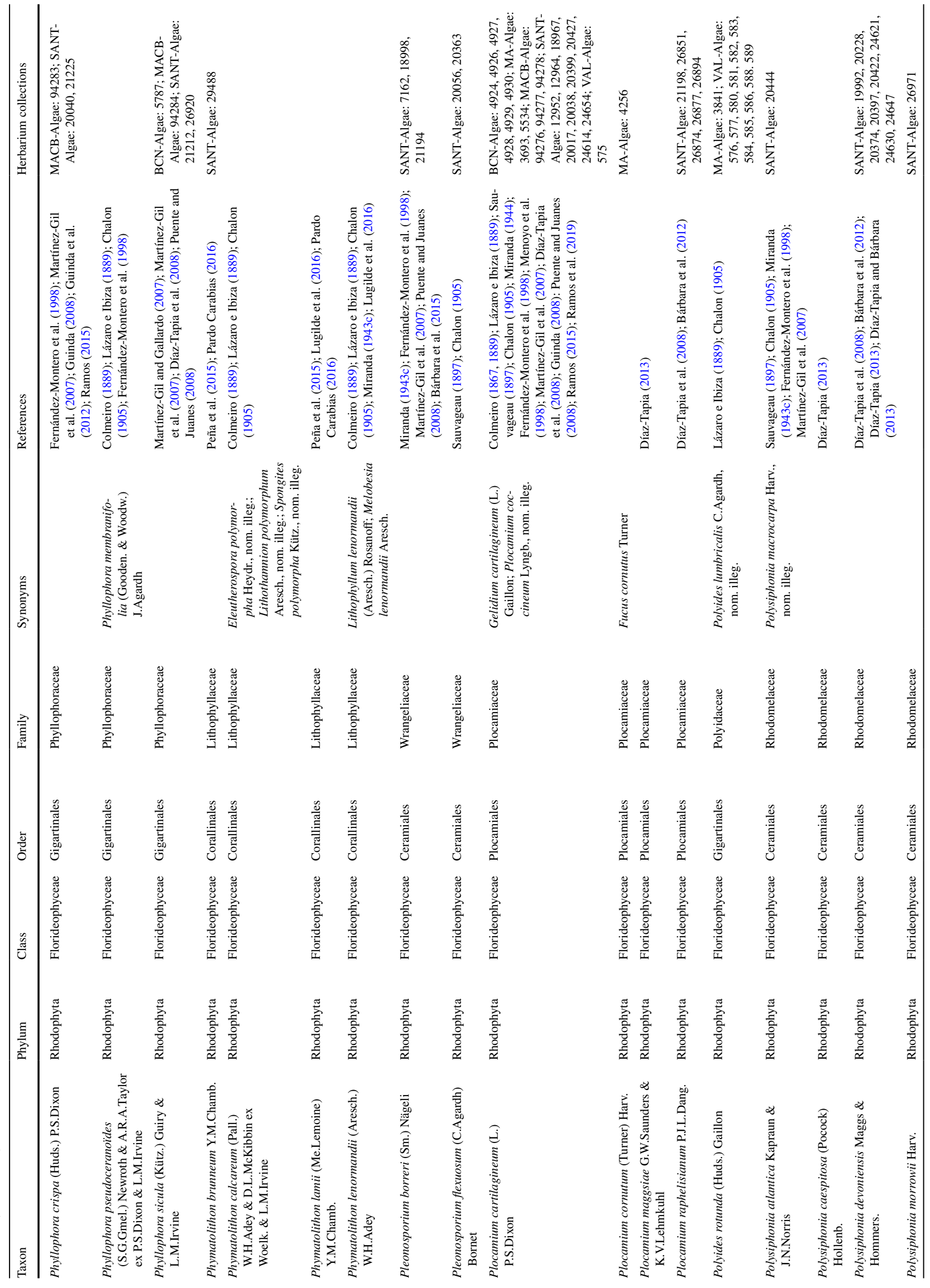



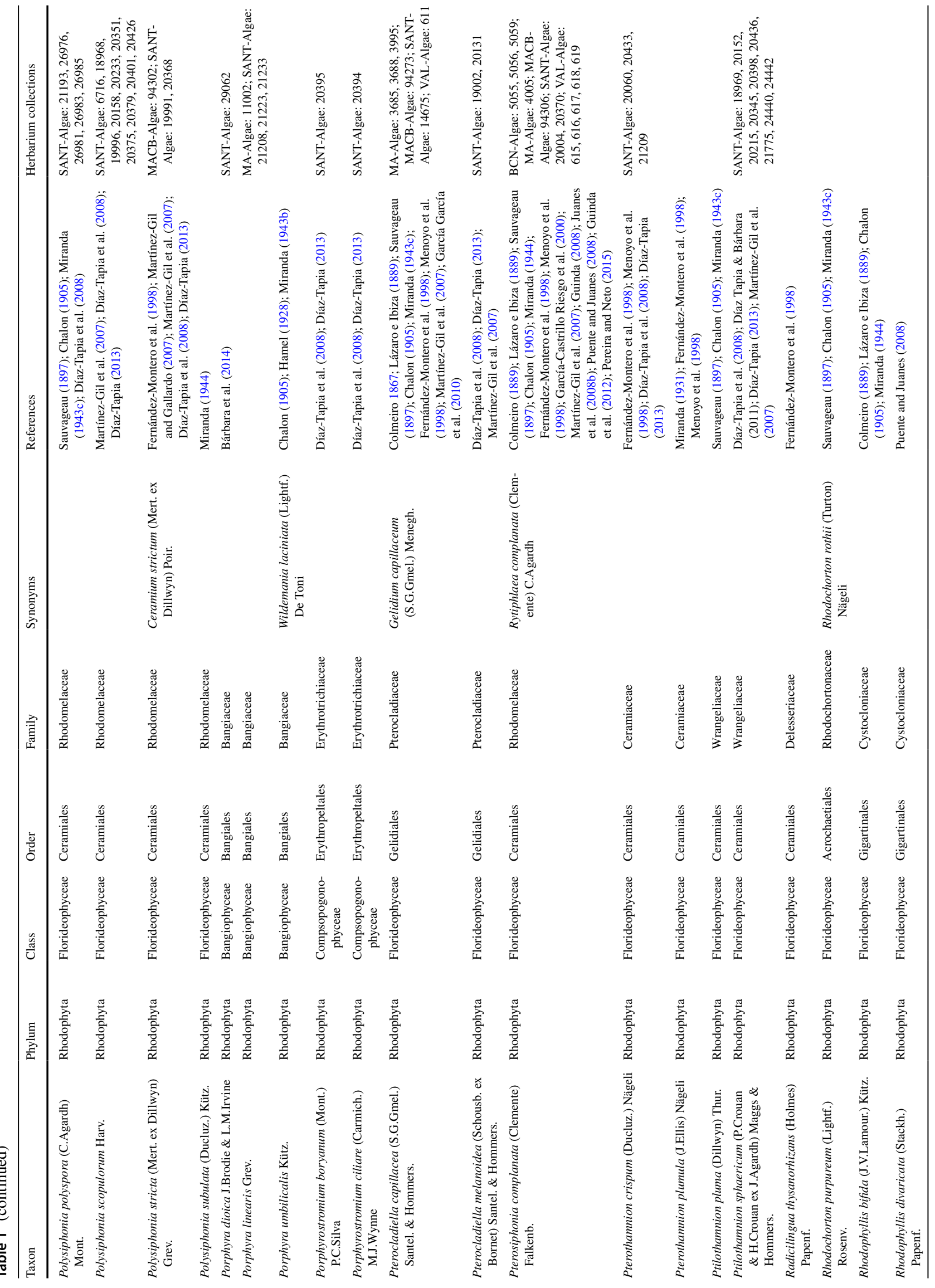


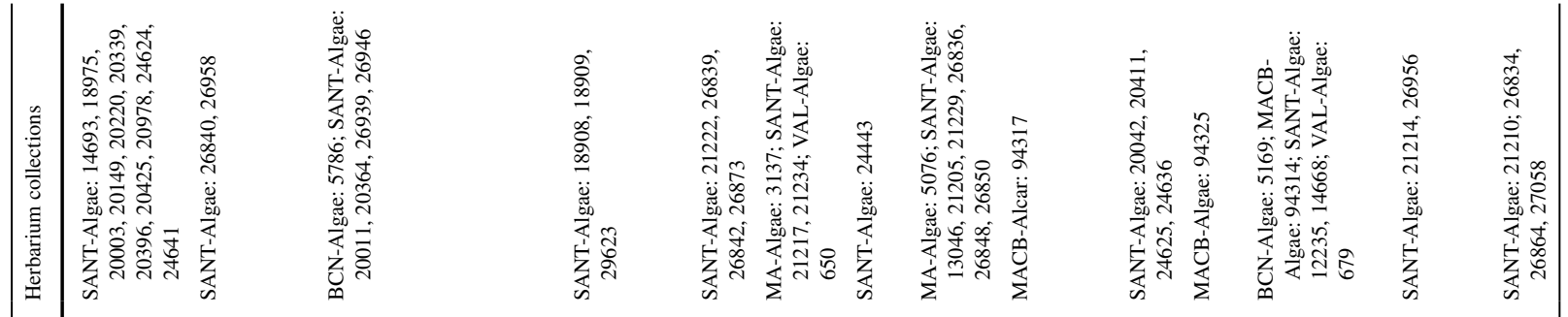

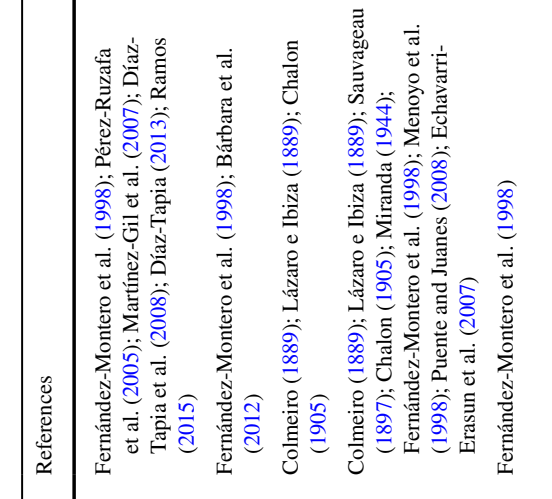

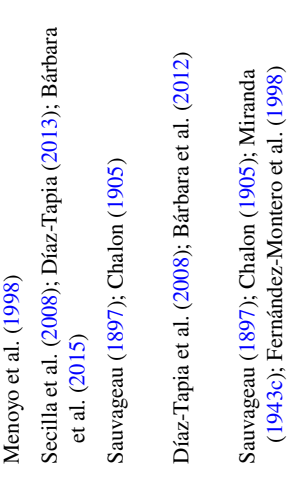

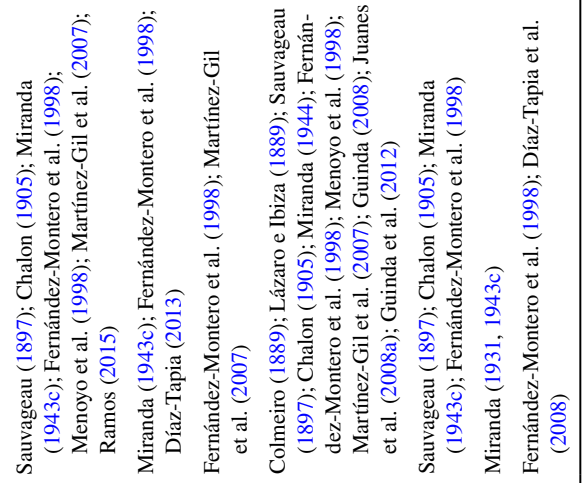

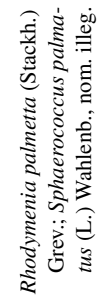

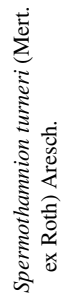

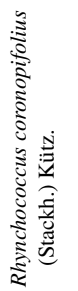

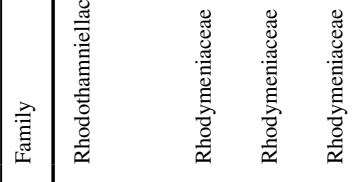

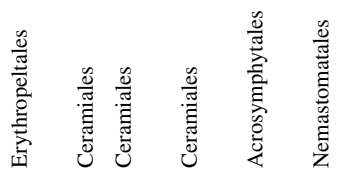

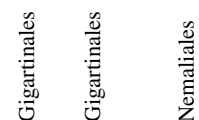

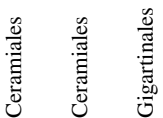

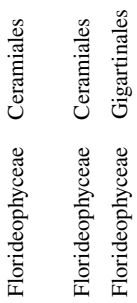

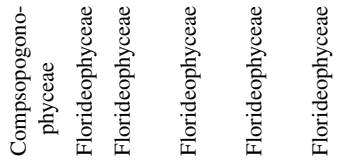

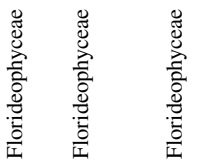

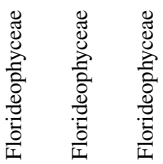

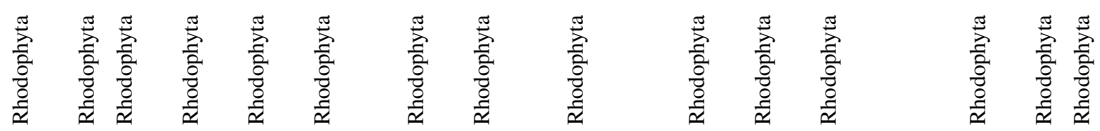

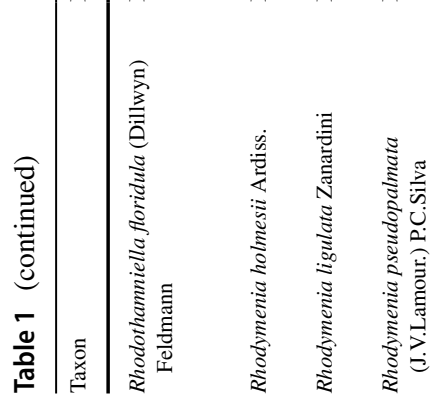
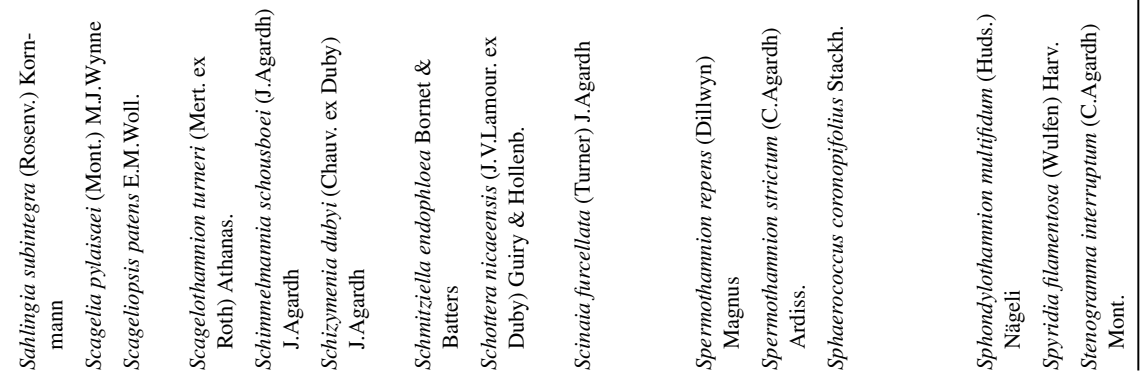


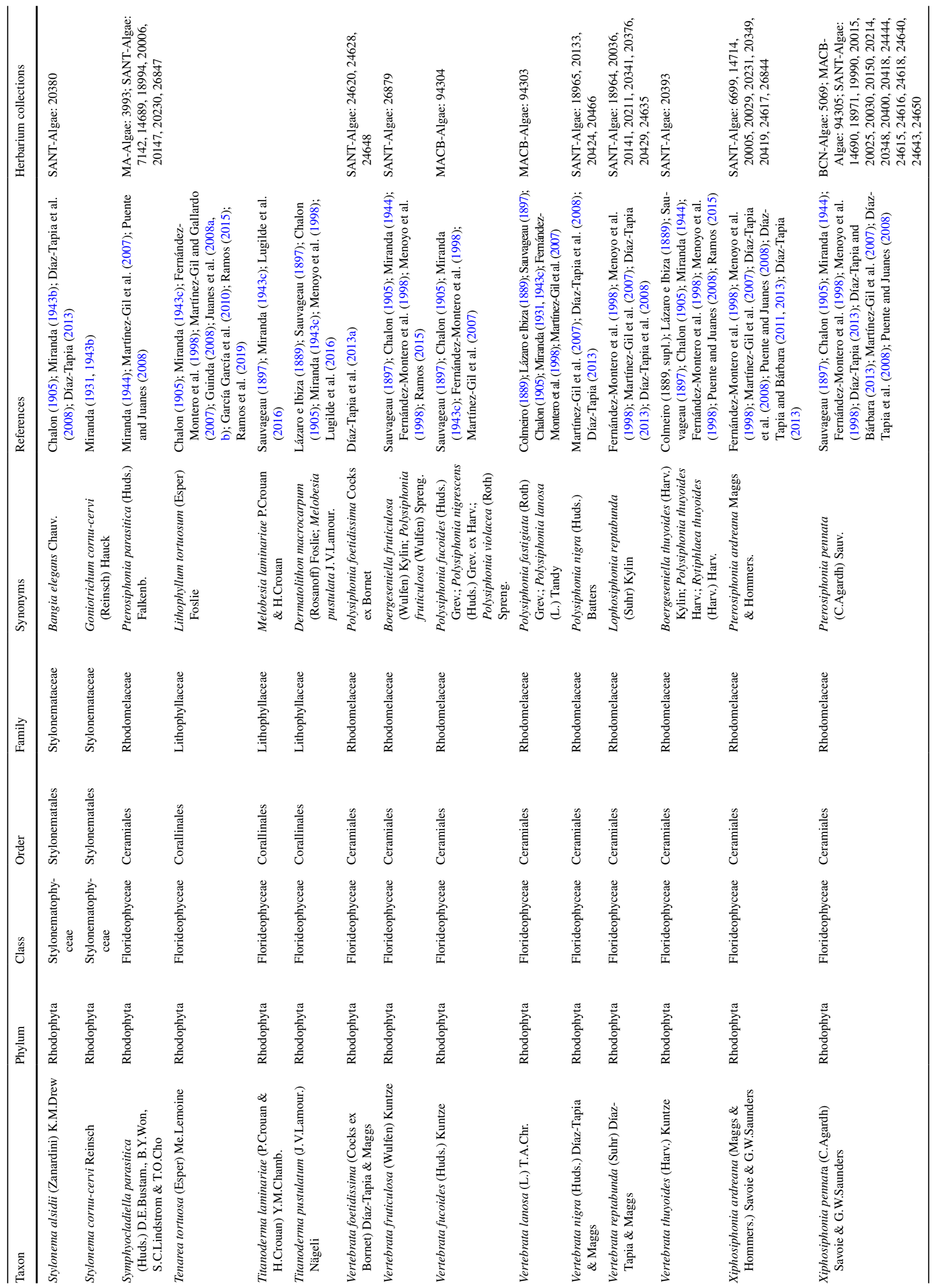




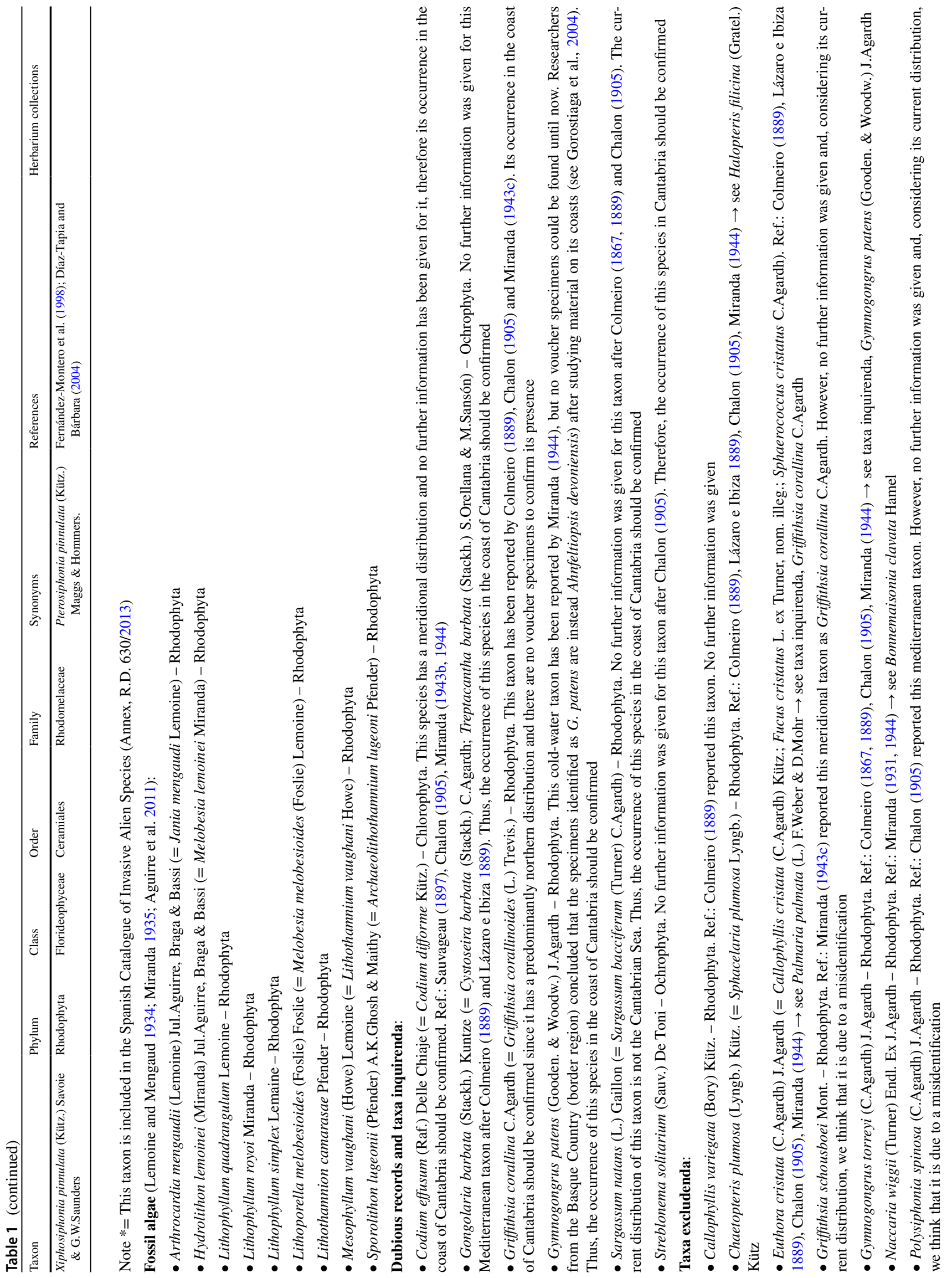


Table 2 Main taxonomic figures of the macroalgal flora of Cantabria (Spain)

\begin{tabular}{llclcc}
\hline Phylum & Class & Order & Family & Total taxa & Total species \\
\hline Chlorophyta & 2 & 5 & 13 & 57 & 55 \\
Ochrophyta & 1 & 10 & 20 & 89 & 81 \\
Rhodophyta & 4 & 22 & 51 & 266 & 264 \\
Total & 7 & 37 & 84 & 412 & 400 \\
\hline
\end{tabular}

6 further taxa. The confirmed species (Table 2) comprise 7 classes, 37 orders and 84 families of macroalgae (excluding cyanophytes). Additionally, 9 fossil algae were registered.

\section{Discussion}

Previous studies conducted in Cantabria (see FernándezMontero et al. 1998; Menoyo et al. 1998; Martínez-Gil et al. 2007) reported the presence of 252 seaweeds. The 437 taxa reported here increase the total of marine benthic algae recorded in this region by $58 \%$, revealing that seaweed diversity from the Atlantic coast of Southern Europe remains partially unknown. This study reveals the presence of alien species such as Anotrichium furcellatum, Antithamnionella ternifolia, Bonnemaisonia hamifera, Caulacanthus okamurae, Centroceras clavulatum, Ceramium secundatum, Codium fragile, Colpomenia peregrina, Falkenbergia rufolanosa (tetrasporophytic phase of Asparagopsis armata), Grateloupia filicina, Grateloupia subpectinata, Hypnea musciformis, Melanothamnus collabens (= Neosiphonia collabens), Melanothamnus harveyi (= Neosiphonia harveyi), Polysiphonia morrowii, Phycocalidia suborbiculata (= Porphyra suborbiculata), Sargassum muticum, Ulva australis, Umbraulva dangeardii and Undaria pinnatifida, all of which are also present in other nearby Cantabrian regions.

Table 3 Number of species and percentages of each algae group in the Cantabrian coast, including Cheney's ratio

\begin{tabular}{lllll}
\hline & Chlorophyta & Ochrophyta & Rhodophyta & $\begin{array}{l}\text { Cheney’s } \\
\text { ratio }\end{array}$ \\
\hline $\begin{array}{l}\text { Fernández- } \\
\text { Montero et al. } \\
(1998)\end{array}$ & $31(16 \%)$ & $39(20 \%)$ & $127(64 \%)$ & 4.05 \\
$\begin{array}{c}\text { Menoyo et al. } \\
(1998)\end{array}$ & $18(16 \%)$ & $26(22 \%)$ & $72(62 \%)$ & 3.46 \\
$\begin{array}{c}\text { Martínez-Gil } \\
\text { et al. (2007) }\end{array}$ & $18(12 \%)$ & $26(23 \%)$ & $63(65 \%)$ & 3.03 \\
\begin{tabular}{c} 
Present study \\
\hline
\end{tabular} & $55(14 \%)$ & $81(20 \%)$ & $264(66 \%)$ & 3.93 \\
\hline
\end{tabular}

Information provided covers main algal flora and the present work
It is worth mentioning that considering Cheney's ratio ([Rhodophyta+Chlorophyta]/Ochrophyta), all values fell within the range of 3.42 to 4.15 (Table 3). A closer look to this ratio showed that nearby regions such as Basque Country, Asturias and Galicia present ratios of 4.09 (Gorostiaga et al. 2004), 2.91 (Cires and Cuesta 2010) and 2.94 (Bárbara et al. 2005), respectively. Based on this, the flora of Cantabria (3.93) appears to be closer to the one of Basque Country, possibly indicating its warm-water character.

Our data indicates that the coast of Cantabria sustains a relatively rich marine macroalgal flora and confirms that the Atlantic coast is a suitable geographic location for the settlement of macroalgae with different biogeographical affinities. Despite this richness, specific habitats and locations remain fully or partially overlooked (e.g., subtidal environments or certain groups that required detailed studies such as Cyanobacteria). The present study aims to contribute to fill those gaps, ultimately deepening the knowledge of the macroalgal flora of Cantabria, as well as its connections with other bordering territories.

Acknowledgements The present manuscript is dedicated to the memory of Prof. José Antonio Fernández Prieto, for his love to Cantabria and Torrelavega. Also, our most sincere gratitude goes to Pablo González-Suárez, Marta Pérez and Thomas E. Holloway for the English correction.

Funding Open Access funding provided thanks to the CRUE-CSIC agreement with Springer Nature.

\section{Declarations}

Conflict of interest On behalf of all authors, the corresponding author states that there is no conflict of interest.

Open Access This article is licensed under a Creative Commons Attribution 4.0 International License, which permits use, sharing, adaptation, distribution and reproduction in any medium or format, as long as you give appropriate credit to the original author(s) and the source, provide a link to the Creative Commons licence, and indicate if changes were made. The images or other third party material in this article are included in the article's Creative Commons licence, unless indicated otherwise in a credit line to the material. If material is not included in the article's Creative Commons licence and your intended use is not permitted by statutory regulation or exceeds the permitted use, you will need to obtain permission directly from the copyright holder. To view a copy of this licence, visit http://creativecommons.org/licenses/by/4.0/.

\section{References}

Aguirre J, Braga JC, Bassi D (2011) Taxonomic assessment of coralline algal species (Rhodophyta; Corallinales and Sporolithales) described by Pfender, Lemoine, and Miranda from northern Spain type localities. Ann Naturhist Mus Wien 113:267-289

APROMAR 2014. Evaluación del estado de explotación y propuestas de gestión sostenible y cultivo de macroalgas en Andalucía, 
Asturias y Galicia. www.apromar.es/content/documentosfinal es-proyecto-algas. Accessed 16 Mar 2021

Araújo R, Bárbara I, Santos G, Rangel M, Sousa Pinto I (2003) Fragmenta Chorologica Occidentalia, Algae. Anales Jard Bot Madrid 60:405-409

Araújo R, Bárbara I, Tibaldo M, Berecibar E, Díaz-Tapia P, Pereira R, Santos R, Pinto IS (2009) Checklist of benthic marine algae and cyanobacteria of northern Portugal. Bot Mar 52(1):24-46

Ardré F (1970) Contribution à l'étude des algues marines du Portugal. I. La flore. Port Acta Biol 10:137-555

Arroyo NL (2002) Meiofauna asociada al alga Laminaria ochroleuca de la Pylaie en la isla de Mouro (Santander, Cantabria). Tesis Doctoral. Universidad Complutense de Madrid

Arroyo NL, Maldonado M, Pérez-Portela R, Benito J (2004) Distribution patterns of meiofauna associated with a sublittoral Laminaria bed in the Cantabrian Sea (north-eastern Atlantic). Mar Biol 144:231-242

Bárbara I, Calvo S, Cremades J, Díaz P, Dosil J, Peña V, López Varela C, Novo T, Veiga AJ, López Rodríguez MC (2003) Fragmenta Chorologica Occidentalia, Algae 8641-8747. Anales Jard Bot Madrid 60:409-419

Bárbara I, Clerck O, De, García-Redondo V, Peña V, García-Fernández A, Peteiro C, Sánchez N (2015) Nuevas citas y adiciones corológicas para la flora bentónica marina del atlántico ibérico. Acta Bot Malac 40:191-237

Bárbara I, Cremades J, Calvo S, López Rodríguez MC, Dosil J (2005) Checklist of the benthic marine and brackish Galician algae (NW Spain). Anales Jard Bot Madrid 62(1):69-100

Bárbara I, Cremades J, Veiga AJ, López-Varela C, Dosil J, Calvo S, Peña V, López-Rodríguez MC (2002) Fragmenta Chorologica Occidentalia, Algae, 7814-7892. Anales Jard Bot Madrid 59(2):292-297

Bárbara I, Díaz P, Araújo R, Peña V, Berecibar E, Cremades J, Freire O, Baamonde S, Novo T, Calvo S, López Rodríguez MC, AfonsoCarrillo J, Clerck O, De, Santos R, Sousa-Pinto I, Tibaldo M, Lagos V, López C, Secilla A, Santolaria A, Díez I, Veiga AJ (2006) Adiciones corológicas y correcciones a la flora bentónica marina del norte de la Península Ibérica. Nova Acta Ci Compostelana $15: 77-88$

Bárbara I, Díaz P, Peteiro C, Berecibar E, Peña V, Sánchez N, Tavares AM, Santos R, Secilla A, Riera-Fernández P, Bermejo R, García V (2012) Nuevas citas y aportaciones corológicas para la flora bentónica marina del Atlántico de la Península Ibérica. Acta Bot Malac 37:5-32

Bárbara I, García-Redondo V, Díaz-Tapia P, García-Fernández A, Piñeiro-Corbeira C, Peña V, Lugilde J, Cremades J (2019) Adiciones y correcciones a la flora bentónica marina del Atlántico ibérico norte. Acta Bot Malac 44:51-60

Bárbara I, Peteiro C, Peña V, Altamirano M, Piñeiro-Corbeira C, Sánchez N, Díaz-Tapia P, García-Redondo V, García-Fernández A, Zanolla M (2014) Nuevas citas y adiciones corológicas para la flora bentónica marina del atlántico ibérico. Acta Bot Malac 39:207-237

Barceló MC, Gómez Garreta A, Ribera MA, Rull Lluch J (1998) Mapas de distribución de algas marinas de la Península Ibérica e Islas Baleares. XI. Lobophora variegata (Lamour.) Womersley, Padina pavonica (L.) Thivy y Zonaria tournefortii (Lamour.) Mont. (Dictyotales, Fucophyceae) Bot Complut 22:179-186

Barceló MC, Gómez Garreta A, Rull Lluch J, Ribera MA (1994) Mapas de distribución de algas marinas de la Península Ibérica e Islas Baleares. VI. Cystoseira. C. Agardh: Grupos C. spinifero-opuntioides y C. discors-abrotanifolioides. Bot Complut 19:119-130

Chalon J (1905) Liste des algues marines observées jusqu'à ce jour entre l'Embouchure de l'Escaut et la Corogne (incl. Iles AngloNormandes). Imprimerie J.-E. Buschmann, rempart de la Porte du Rhin, Anvers
Cheney DF (1977) R \& C/P, a new and improved ratio for comparing seaweed floras. J Phycol 13:12

Cires E, Cuesta C (2010) Checklist of Benthic algae from the Asturias coast (North of Spain). Bol Cien Nat RIDEA 51:135-212

Cires E, Cuesta C (2019) Addenda to the checklist of benthic algae from Asturias (north of Spain). Bol Cien Nat y Tecnología RIDEA 54:33-46

Clemente y Rubio SR (1807). Ensayo sobre las variedades de la vid común que vegetan en Andalucía, con un índice etimológico y tres listas de plantas en que se caracterizan varias especies nuevas. Imprenta de Villalpando, Madrid

Colmeiro M (1867) Enumeración de las criptógamas de España y Portugal. Rev Progr Ci Exact 16-17:1-160

Colmeiro M (1889) Enumeración y revisión de las plantas de la Península Hispano-Lusitana é islas Baleares. Tomo V (Monocotiledóneas y criptógamas). Imprenta de la viuda é hija de Fuentenebro, Madrid

Conde F, Gallardo T (2002) Mapas de distribución de algas marinas de la Península Ibérica e Islas Baleares. XIV. Calliblepharis (Cystocloniaceae, Gigartinales, Rhodophyceae). Bot Complut 26:137-146

Cremades J, Bárbara I, Veiga AJ, López Rodríguez MC (2002) Fragmenta Chorologica Occidentalia, Algae, 7776-7812. Anales Jard Bot Madrid 59:289-291

Díaz-Tapia P (2013) Estudio ficológico de los hábitats rocoso-arenosos del Atlántico Peninsular. Tesis doctoral, Departamento de Bioloxía Animal, Bioloxia Vexetal e Ecoloxía, Universidad de A Coruña

Díaz-Tapia P, Bárbara I (2004) Pterosiphonia pennata versus P. pinnulata (Ceramiales, Rhodophyta) en el noroeste de la Península Ibérica. An Biol 26:47-59

Diaz-Tapia P, Bárbara I (2011) Sexual structures in Ptilothamnion sphaericum and Pterosiphonia complanata (Ceramiales, Rhodophyta) from the Atlantic Iberian Peninsula. Bot Mar 54(1):35-46

Díaz-Tapia P, Bárbara I (2013) Seaweeds from sand-covered rocks of the Atlantic Iberian Peninsula. Part 1. The Rhodomelaceae (Ceramiales, Rhodophyta). Cryptogam, Algol 34(4):325-422

Díaz-Tapia P, Bárbara I (2014) Seaweeds from sand-covered rocks of the Atlantic Iberian Peninsula. Part 2. Palmariales, Ceramiales (excluding Rhodomelaceae), Gelidiales, Gigartinales, Plocamiales, Rhodymeniales and Scytothamnales. Cryptogam, Algol 35(2):157-199

Díaz-Tapia P, Bárbara I, Secilla S, Peteiro C, Calvo S, Sánchez N, Santolaria A, Díez I, Gallardo T, Cremades J, Gorotiaga JM (2008) Adiciones corológicas a la flora bentónica marina de Cantábrico. Acta Ci Compostelana 17:177-189

Díaz-Tapia P, Kim MS, Secilla A, Bárbara I, Cremades J (2013a) Taxonomic reassessment of Polysiphonia foetidissima (Rhodomelaceae, Rhodophyta) and similar species, including $P$. schneideri, a newly introduced species in Europe. Eur J Phycol 48(4):345-362

Díaz-Tapia P, Maggs CA, Macaya EC, Verbruggen H (2018) Widely distributed red algae often represent hidden introductions, complexes of cryptic species or species with strong phylogeographic structure. J Phycol 54(6):829-839

Díaz-Tapia P, Min Boo S, Geraldino PJL, Bárbara I, Hommersand MH (2013b) Morphology and systematics of Calliblepharis hypneoides, sp. nov. (Cystocloniaceae, Rhodophyta) from the Atlantic Iberian Peninsula. Eur J Phycol 48(4):380-397

Dizerbo AH (1956) Notes sur la flore marine de la cóte atlantique de l'Espagne. Collect Bot (Barcelona) 5:269-278

Duarte L, Viejo RM, Martínez B, Decastro M, Gómez-Gesteira M, Gallardo T (2013) Recent and historical range shifts of two canopy-forming seaweeds in North Spain and the link with trends in sea surface temperatures. Acta Oecol 51:1-10 
Echavarri-Erasun B, Juanes JA, García-Castrillo G, Revilla JA (2007) Medium-term responses of rocky bottoms to sewage discharges from a deepwater outfall in the NE Atlantic. Mar Pollut Bull 54:941-954

Escudero MC, Gallardo T, Bárbara I, Acrosorium (2009) Cryptopleura, Gonimophyllum (Delesseriaceae, Ceramiales, Rhodophyceae). Bot Complut 33:105-118

Feldmann J (1937) Recherches sur la végétation marine de la Méditerranée. La côtes des Albères. Rev Algol 10:1-339

Fernández-Montero L, Pérez-Ruzafa IM, Cubero I, Gallardo T (1998) Catálogo de la flora bentónica marina de la Ría de Tina Menor y costa de Pechón (Cantabria). Bot Complut 22:83-100

Fischer-Piette E, Ginsburg-Ardré F (1963) Le difficile repeuplement en Himanthalia de la cóte de Santander. Rev Algol 6:324-329

Gallardo T, Bárbara I, Afonso-Carrillo J, Bermejo R, Altamirano M, Gómez Garreta A, Barceló Martí MC, Rull Lluch J, Ballesteros E, De La Rosa J (2016) Nueva lista crítica de las algas bentónicas marinas de España. Algas 51:7-52

Gallardo T, Casado M (2000) Mapas de distribución de algas marinas de la Península Ibérica e Islas Baleares. XIII. Mastocarpus stellatus (Stackh.) Guiry (Petrocelidaceoe, Rhodophyceae). Bot Complut 24:107-111

García Fernández A (2020) La comunidad de Cystoseira baccata (Fucales, Ochrophyta) en el noroeste ibérico. Tesis Doctoral, Universidade da Coruña

García García AI, Otero Gómez S, Tordesillas Gómez E (2010) Patrimonio litoral de Cantabria. Guía del intermareal. Algas-Invertebrados. ACEM Santander

García-Castrillo Riesgo G, Serrano A, Preciado I, Rodríguez C, Puente A, Juanes J (2000) Estructuración biocenótica de la comunidad de laminariales de la Isla de Mouro (Mar Cantábrico, Santander). Bol Soc Oceanogr Guipúzcoa 3:85-99

GBIF (2021) GBIF Home Page. https://www.gbif.org. 16 Mar 2021

GESHA (2005) Cartografiado bionómico del litoral de Cantabria. Grupo de Emisarios Submarinos e Hidráulica Ambiental. Universidad de Cantabria, Gobierno de Cantabria

Gómez Garreta A (ed) (2000) Flora Phycologica Iberica, I. Fucales. Universidad de Murcia, Murcia

Gómez Garreta A, Ribera MA, Barceló MC, Rull Lluch J (1994) Mapas de distribución de algas marinas de la Península Ibérica e Islas Baleares. V. Cystoseira C Agardh: Grupos C. ericaefolia y $C$. crinito-selaginoides. Bot Complut 19:109-118

Gómez Garreta A, Ribera MA, Barceló MC, Rull Lluch J (2002) Mapas de distribución de algas marinas de la Península Ibérica y las Islas Baleares. XVI. Dictyopteris polypodioides (DC.) Lamour. y Spatoglossum solieri (Chauv. ex Mont.) Kütz. Bot Complut 26:153-160. (Dictyotales, Fucophyceae)

Gorostiaga JM, Santolaria A, Secilla A, Casares C, Díez I (2004) Check-list of the Basque coast benthic algae (N Spain). Anales Jard Bot Madrid 61:155-180

Guinda X (2008) Desarrollo de procedimientos aplicables a la evaluación del estado ecológico de las masas de agua costeras, sensu Directiva Marco del Agua. Tesis doctoral, Universidad de Cantabria

Guinda X, Gracia A, Puente A, Juanes JA, Rzhanov Y, Mayer LA (2014) Application of landscape mosaics for the biological quality assessment of subtidal macroalgae communities using the CFR index. Deep-Sea Res 106:207-215

Guinda X, Juanes JA, Puente A, Echavarri-Erasun B (2012) Spatial distribution pattern analysis of subtidal macroalgae assemblages by a non-destructive rapid assessment method. J Sea Res 67(1):34-43

Guiry MD, Guiry GM (2021) AlgaeBase. World-wide electronic publication, National University of Ireland, Galway. https://www. algaebase.org. 18 June 2021
Hamel G (1928) Algas marinas de España y Portugal. I. Protoflorídeas o Bangiales. Bol Real Soc Esp Hist Nat 28:167-170

Hernández-Kantún JJ, Rindi F, Adey WH, Heesch S, Peña V, Le Gall L, Gabrielson PW (2015) Sequencing type material resolves the identity and distribution of the generitype Lithophyllum incrustans, and related European species L. hibernicum and L. bathyporum (Corallinales, Rhodophyta). J Phycol 51(4):791-807

Izquierdo JL, Gallardo García T, Pérez-Ruzafa IA (1995) Mapas de distribución de algas marinas de la Península Ibérica e Islas Baleares. IX. Saccorhiza polyschides (Lightf.) Batt. y Chorda filum (L.) Stackh. (Laminariales, Fucophyceae). Bot Complut 20:105-116

Izquierdo JL, Navarro M, Gallardo T (1993) Mapas de distribución de algas marinas de la Península Ibérica, IV. Laminaria ochroleuca Pylaie, L. hyperborea (Gunner.) Foslie y L. saccharina (L.) Lamour. Bot Complut 18:291-304

Juanes JA, Guinda X, Puente A, Revilla JA (2008a) Macroalgae, a suitable indicator of the ecological status of coastal rocky communities in the NE Atlantic. Ecol Indic 8:351-359

Juanes JA, Gutiérrez L (1991) Cartografía y evaluación de biomasa de Gelidium sesquipedale (Clem). Born. et Thur. en la costa oriental de Cantabria (N. de España). Inf Tec Sci Mar 166:1-22

Juanes JA, Puente A, Revilla JA (2008b) Comparison of two methods for quality assessment of macroalgae assemblages, under different pollution types. Ecol Indic 8:743-753

Lázaro e Ibiza B (1889) Datos para la flora algológica del norte y noroeste de España. Anales Soc Esp Hist Nat 18:275-294

Lazzo G, Gallardo T (2004) Estudio de la morfología y de las estructuras reproductoras de Mastocarpus stellatus (Stackhouse) Guiry (Gigartinales, Rhodophyta) en las costas de la Península Ibérica. Bot Complut 28:21-26

Lemoine MP, Mengaud L (1934) Algues calcaires de l'Éocène de la province de Santander, Espagne). Bull Soc Hist Nat Toulouse 66:171-180

López Mecández J (2017) Modelado ecológico de las praderas de Gelidium corneum en el Mar Cantábrico. Máster Universitario en Gestión Integrada de Sistemas Hídricos, Universidad de Cantabria

Lugilde J, Peña V, Bárbara I (2016) The order Corallinales sensu lato (Rhodophyta) in the Iberian Atlantic: current state of knowledge. Anales Jard Bot Madrid 73(2):e038

Margalet JL, Almaraz T, Navarro MJ, Pérez-Ruzafa IM (1993) Mapas de distribución de algas marinas de la Península Ibérica, III. Fucus ceranaides L., F. serratus L. Fucus spiralis L. y Fucus vesiculosus L. Bot Complut 18:267-290

Margalet JL, Navarro MJ (1990) Mapas de distribución de algas marinas de la Península Ibérica, I. Bifurcaria bifurcata R. Ross y Halidrys siliquosa (L.) Lyngb. Bot Complut 16:99-107

Margalet JL, Navarro MJ (1992) Mapas de distribución de algas marinas de la Península Ibérica, II. Ascophyllum nodosum (L.) Le Jolis, Pelvetia canaliculata (L.) Decne. et Thnr. e Himanthalia elongata (L.) S. F. Cray. Bot Complut 17:117-132

Martínez-Gil M, Gallardo T (2007) Aportación al conocimiento de las algas marinas bentónicas del litoral comprendido entre el estuario del río Quejo y Punta de la Mesa. Cantabria Algas 37:7-8

Martínez-Gil M, Gallardo T, Díaz P, Bárbara I (2007) Aportación al conocimiento de las algas marinas bentónicas del litoral comprendido entre el estuario del río Quejo y Punta de la Mesa, Noja, Cantabria, España. Bot Complut 31:41-53

Menoyo D, Gallardo T, Pérez-Ruzafa IM (1998) Catálogo de la flora bentónica marina de punta Sonabia a Punta Cotolino (Cantabria). Bot Complut 22:101-112

Miranda F (1931) Sobre las algas y cianofíceas del Cantábrico especialmente de Gijón. Trab Mus Nac Ci Nat 25:7-106 
Miranda F (1932) Adiciones y correcciones a la lista de algas marinas de Gijón. Bol R Soc Esp Hist Nat 32:435-438

Miranda F (1935) Algas Coralináceas fósiles del Terciario de San Vicente de la Barquera (Santander). Bol R Soc Esp Hist Nat 35:279-287

Miranda F (1943a) Enumeración de las algas marinas del N. y NO. de España. Ciencia (México) 4(1):17-20

Miranda F (1943b) Enumeración de las algas marinas del N. y NO. de España (continuación). Ciencia (México) 4(4/5):111-116

Miranda F (1943c) Enumeración de las algas marinas del N. y NO. de España (continuación). Ciencia (México) 4(6/7):156-161

Miranda F (1944) Enumeración de las algas marinas del N. y NO. de España (continuación). Ciencia (México) 4(8/10):219-224

O'Dwyer JA, Afonso-Carrillo J (2001) Vegetative and reproductive morphology of Helminthora calvadosii, $H$. agardhiana and $H$. reyesii sp. nov. (Liagoraceae, Rhodophyta) from the eastern Atlantic. Phycologia 40:53-66

Pardo C, Peña V, Barreiro R, Bárbara I (2015) A molecular and morphological study of Corallina sensu lato (Corallinales, Rhodophyta) in the Atlantic Iberian Peninsula. Cryptogam, Algol 36(1):31-54

Pardo Carabias C (2016) Desarrollo y aplicación de marcadores moleculares a especies formadoras de maërl en Europa: datos para su conservación. Tesis Doctoral, Universidad de A Coruña

Pena Martín C, Gómez Garreta A, Crespo MB (2011) Mapas de distribución de algas marinas de la Península Ibérica y las islas Baleares. XXVIII. Dasya (Ceramiales, Rhodophyta). Bot Complut 35:163-173

Peña V, Pardo C, López L, Carro B, Hernández-Kantún J, Adey WH, Bárbara I, Gall LLe (2015) Phymatolithon lusitanicum sp. nov. (Hapalidiales, Rhodophyta): the third most abundant maerlforming species in the Atlantic Iberian Peninsula. Cryptogam, Algol 36(4):429-459

Peña V, de G Torres TR (2021) Lithophyllum artabricum V.Peña, sp. nov. (Corallinales, Rhodophyta): a cryptic species in the Atlantic Iberian Peninsula hitherto assigned to Lithophyllum stictiforme (Areschoug) Hauck Cryptogam. Algol 42(11):153-172

Pereira L, Neto JM (Eds) (2015) Marine algae biodiversity, taxonomy, environmental assessment, and biotechnology. CRC Press, Boca Raton

Pérez-Ruzafa I, Izquierdo JL, Araújo R, Sousa-Pinto I, Pereira L, Bárbara I (2003) Mapas de distribución de las algas marinas de la Península Ibérica e Islas Baleares. XVII. Laminaria rodriguezii Bornet y adiciones a los mapas de L. hyperborea (Gunner.) Foslie, L. ochroleuca Bach. Pyl. y L. saccharina (L.) Lamour. (Laminariales, Fucophyceae). Bot Complut 27:155-164

Pérez-Ruzafa I, Lazzo G, Conde Poyales F (2005) Mapas de distribución de algas marinas de la Península Ibérica e Islas Baleares. XIX. Palmaria palmata y Rhodothamniella floridula (Palmariales, Rhodophyta). Bot Complut 29:71-75

Pérez-Ruzafa LM, Gallardo T (1997) Mapas de distribución de algas marinas de la Península Ibérica e Islas Baleares. X. Variedades dc Fucus spiralis L. y de F. vesiculosus L. (Fucales, Fucophyceae). Bot Complut 21:121-136

Pérez-Ruzafa LM, Gallardo T (1998) Mapas de distribución de algas marinas de la Península Ibérica e Islas Baleares. XII. Adiciones al Orden Fucales (Fucophyceae). Bot Complut 22:187-192

Peteiro C, Sánchez N, Dueñas-Liaño C, Martínez B (2014) Open-sea cultivation by transplanting young fronds of the kelp Saccharina latissima. J Appl Phycol 26:519-528

Peteiro C, Sánchez N, Martínez B (2016) Mariculture of the Asian kelp Undaria pinnatifida and the native kelp Saccharina lattisima along the Atlantic coast of southern Europe: An overview. Algal Res 15:9-23

Polifrone M, Viera-Rodríguez MA, Suárez-Santana J, Lazzo G, PérezRuzafa I (2005) Mapas de distribución de algas marinas de la
Península Ibérica e Islas Baleares. XX. Gracilaria corallicola, G. gracilis, G. multipartita y Gracilariopsis longissima (Gracilariales, Rhodophyta). Bot Complut 29:77-83

Puente A (2000) Distribución y estructura de las comunidades de macroalgas de la Isla de Mouro (Cantabria, Golfo de Vizcaya). Consideraciones sobre su aplicación en la vigilancia ambiental de espacios litorales. Tesis Doctoral, Universidad de Cantabria

Puente A, Juanes JA (2008) Testing taxonomic resolution, data transformation and selection of species for monitoring macroalgae communities. Estuar Coast Shelf 78:327e340

Ramos E (2015) Clasificación física del intermareal rocoso y distribución de macroalgas a diferentes escalas espaciales a lo largo del NE Atlántico. Tesis Doctoral, Universidad de Cantabria, Santander

Ramos E, Puente A, Juanes JA (2019) Cover of intertidal macroalgae along the N and NW coast of the Iberian Peninsula in 2011. Environmental Hydraulics Institute, IHCantabria), Spain. EurOBIS

Real Decreto 630/ (2013) de 2 de agosto, por el que se regula el Catálogo español de especies exóticas invasoras (BOE-A2013-8565, 03/08/2013)

Ribera MA, Gómez Carreta A, Barceló MC, Rull Lluch J (1995) Mapas de distribución de algas marinas de la Península Ibérica e Islas Baleares, VIII. Cystoseira C. Agardh y Sargassum C. Agardh. Bot Complut 20:89-103

Robuchon M, Le Gall L, Gey D, Valero M, Vergés A (2014) Kallymenia crouaniorum (Kallymeniaceae, Rhodophyta), a new red algal species from the Laminaria hyperborea understorey community. Eur J Phycol 49(4):493-507

Rojo I, Olabarria C, Santamaria M, Provan J, Gallardo T, Viejo RM (2014) Coexistence of congeneric native and invasive species: the case of the green algae Codium spp. in northwestern Spain. Mar Environ Res 101:135-144

Rull Lluch J, Gómez Carreta A, Barceló MC, Ribera MA (1994) Mapas de distribución de algas marinas de la Península Ibérica e Islas Baleares. VII. Cystoseira C. Agardh (Grupo C. baccata) y Sargassum C. Agardh (S. muticum y $S$. vulgare). Bot Complut 19:131-138

Rull Lluch J, Ribera MA, Barceló MC, Gómez Garreta A (2005) Mapas de distribución de algas marinas de la Península Ibérica y las Islas Baleares. XVIII. Dictyota dichotoma, D. linearis y D. mediterranea (Dictyotales, Fucophyceae). Bot Complut 29:63-70

Sauvageau C (1897) Note préliminaire sur les algues marines du Golfe de Gascogne. J Bot (Morot) 11:166-179

Sauvageau C (1899a) Les Acinetospora et la sexualité des Tiloptéridacées. J Bot (Morot) 13:107-127

Sauvageau C (1899b) Les Cutlériacées et leur alternance de génération. Ann Sci Nat, Bot 10:265-362

Sauvageau C (1900-1914) Remarques sur les Sphacélariacées. Féret et fils, Bordeaux

Sauvageau C (1908) Sur deux Fucus récoltés à Arcachon (Fucus platycarpus et Fucus lutarius). Bull Stn Biol Arcachon $11: 65-224$

Sauvageau C (1912) A propos des Cystoseira de Banyuls et Guéthary. Bull Stn Biol Arcachon 14:133-556

Secilla A, Santolaria A, Díez I, Berecibar E, Díaz P, Bárbara I, Gorostiaga JM (2008) Scageliopsis patens (Ceramiales, Rhodophyta) a new introduced species for the European coast. Cryptogam, Algol 39(3):191-199

Seoane-Camba J (1979) Sobre algunas Gelidiaceas nuevas o poco conocidas de las costas españolas. Acta Bot Malac 5:95-112

Silva J, Lezama N, Rull Lluch J (2010) Mapas de distribución de algas marinas de la Península Ibérica y las Islas Baleares. XXIV. Catenella caespitosa, Caulacanthus ustulatus y Feldmannophycus rayssiae (Caulacanthaceae, Rhodophyta). Bot Complut 34:89-93 
Valenzuela Miranda S (1979) Las algas del herbario de F. Miranda. Memoria de Licenciatura. Universidad Complutense de Madrid, Madrid

Valenzuela Miranda S (2005) Catálogo de las Cyanophyta contenidas en los tubos y preparaciones microscópicas de la colección de F. Miranda. Bol Cien Nat RIDEA 49:77-89

Valenzuela S, Pérez-Cirera JL (1982) El herbario de algas marinas españolas de F. Miranda Collect Bot (Barcelona) 13:945-975

Vázquez-Ferreira R, Peña V (2016) Tipo de división en esporocistes de Lithophyllum hibernicum (Corallinales, Rhodophyta) y su implicación en el ciclo vital en el Atlántico europeo. Nova Acta Ci Compostelana 23:99-106

Vergés A, Sánchez N, Peteiro C, Huete-Stauffer T, Polo L, Brodie J (2011) Porphyra suborbiculata (Bangiales, Rhodophyta) in Northern Spain, an asiatic species new to European Atlantic. Eur J Phycol 46:190-191
Vergés A, Sanchez N, Peteiro C, Polo L, Brodie J (2013) Pyropia suborbiculata (Bangiales, Rhodophyta): first records from the northeastern Atlantic and Mediterranean of this North Pacific species. Phycologia 52(2):121-129

Williamson CJ, Perkins R, Yallop ML, Peteiro CS, Sánchez N, Gunnarsson K, Brodie J (2018) Photoacclimation and photoregulationstrategies of Corallina (Corallinales, Rhodophyta) across the NE Atlantic. Eur J Phycol 53:290-306

Yesson Y, Jackson A, Russell S, Williamson CJ, Brodie J (2018) SNPs reveal geographical population structure of Corallina officinalis (Corallinaceae, Rhodophyta). Eur J Phycol 53(2):180-188

Publisher's Note Springer Nature remains neutral with regard to jurisdictional claims in published maps and institutional affiliations. 